\title{
STATIC PERCEPTIONS AND INDIVIDUAL AGENCY: THE SETTLEMENT EXPERIENCES OF FILIPINA FORMER CAREGIVERS IN TORONTO
}

by

Mary Gene De Guzman, BA, York University, 2012

\author{
A Major Research Paper \\ Presented to Ryerson University \\ in partial fulfillment of the requirements for the degree of \\ Master of Arts \\ in the Program of \\ Immigration and Settlement Studies
}

Toronto, Ontario, Canada, 2014

(C) Mary Gene De Guzman 2014 


\section{AUTHOR'S DECLARATION FOR ELECTRONIC SUBMISSION OF A MAJOR RESEARCH PAPER (MRP)}

I hereby declare that I am the sole author of this Major Research Paper. This is a true copy of the MRP, including any required final revision, as accepted by my examiner.

I authorize Ryerson University to lend this MRP to other institutions or individuals for the purpose of scholarly research.

I further authorize Ryerson University to reproduce this MRP by photocopying or by other means, in total or in part, at the request of other institutions or individuals for the purpose of scholarly research.

I understand that my MRP may be made electronically available to the public. 


\title{
STATIC PERCEPTIONS AND INDIVIDUAL AGENCY: THE SETTLEMENT EXPERIENCES OF FILIPINA FORMER CAREGIVERS IN TORONTO
}

\author{
Mary Gene De Guzman
}

Master of Arts 2014

Immigration and Settlement Studies

Ryerson University

\begin{abstract}
Historic and contemporary perceptions of immigrants who came to Canada as live-in caregivers have changed little over time. Gendered, racialized and classed assumptions continue to demarcate belonging and impose obstacles to their successful settlement and integration into Canadian society. However, the notion of success can be interpreted in different and conflicting ways. This paper analyzes the interpretations of settlement for 7 Filipina former caregivers in Toronto, who entered under the Foreign Domestic Movement and the Live-in Caregiver Program, according to their valorization and investment of their different forms of capital, such as educational qualifications or social networks.

Focusing on the subjective and diverse perceptions of these women is integral to reaching a more nuanced understanding of the priorities and values that drive the settlement and integration outcomes of this ethno-cultural group while simultaneously avoiding essentialist practices that normalize their presence as domestic workers.
\end{abstract}

Key words: Filipina, live-in caregiver, settlement, intersectionality, forms of capital 


\section{Acknowledgements}

My heartfelt gratitude goes out to my supervisor, Dr. Rupa Banerjee, who has guided me through this first major academic milestone even while experiencing her first year as a supervisor.

I am also thankful to my second reader, Dr. Harald Bauder who patiently read through both this paper and previous ones in his Settlement Experiences in Canada course that eventually became my inspiration.

This paper would not have been possible without the cooperation of the 7 individuals who agreed to take an hour out of their busy lives to share their experiences with me.

Also, thanks so much to Kienzel Trestiza, Jennifer Doré and Joe Correia who stayed up with me for hours proofreading, checking for consistency, or just providing moral support as I stressed over this project.

Finally, thank you, thank you to my family for always giving me encouragement, love and support. 


\section{Table of Contents}

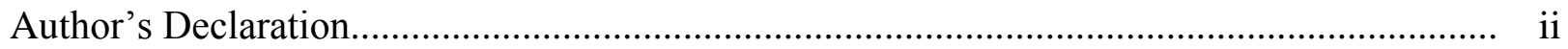

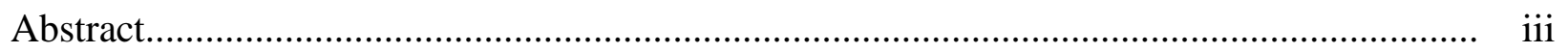

Acknowledgements......................................................................................................... iv

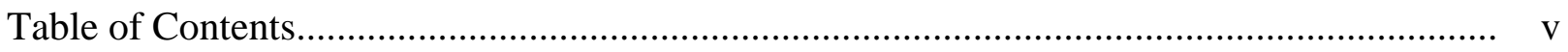

Chapter 1: Introduction ..........................................................................................

Chapter 2: Literature Review

2.1 A Brief History of Domestic Work in Canada........................................................ 4

2.2 Implications of Foreign Domestic Movement and Live-in Caregiver Program

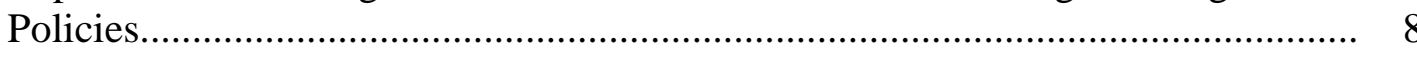

2.3 Economic Barriers of Deskilling and Credential Non-Recognition....................... 12

2.4 Social Networks' Push to Uphold Economic and Cultural Obligations.................. 15

2.5 Construction and Re-construction of Social and Economic Identity..................... 19

Chapter 3: Theoretical Framework and Research Questions: Intersectionality and Forms of

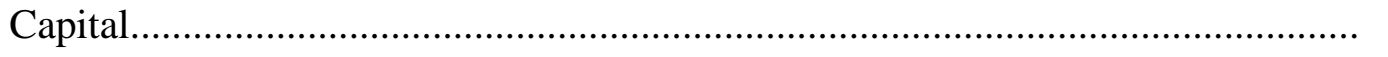

Chapter 4: Methodology

4.1 Positionality and Paradigm: Hybrid Insider-Outsider............................................ 26

4.2 Purposive Sampling and Inductive Inquiry..................................................... 28

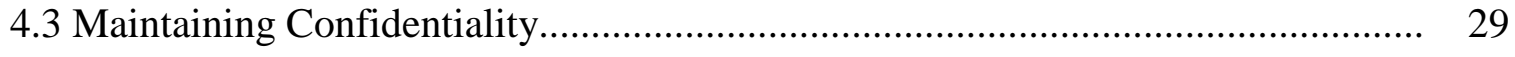

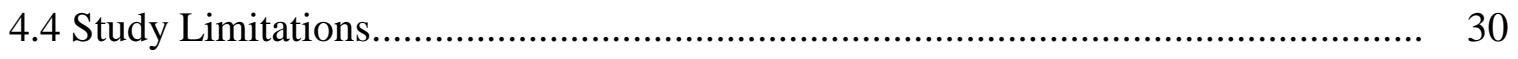

4.5 Study Participants.................................................................................... 31

Chapter 5: Discussion of Participant Narratives

5.1 Social Capital and Employment Agencies: Impact on Employment Outcomes...... 34

5.2 Institutionalized and Embodied Cultural Capital: Structural and Social Barriers to Settlement...... 
5.3 Employment Acquiescence and Settlement Satisfaction........................................ 42

5.4 Individual Agency and Personal Motivation.......................................................... 46

Chapter 6: Conclusion and Recommendations................................................................ 50

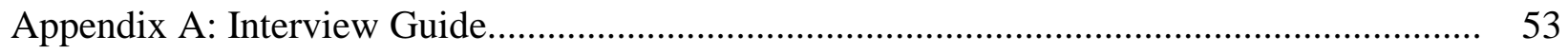

Appendix B: Informed Consent Form............................................................................ 55

Appendix C: Telephone Recruitment Script................................................................ 58

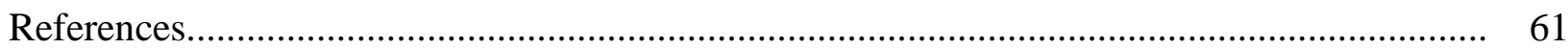




\section{Chapter 1}

\section{Introduction}

Academic and public discussions since the late 1980s and early 1990s of the exploitative migration experiences and treatment of immigrants who enter Canada as live-in domestic workers or caregivers are mired in ideological debates over labour market necessities, sociocultural expectations and moral imperatives. There is no lack of studies or media reports on the controversial working conditions of paid caregiving work, with many sources assigning culpability to government regulations, or lack thereof; or to the gendered, racialized and classed disparities that are propagated and reproduced between employers and employees by caregiving or domestic work (Bourgeault, Parpia and Atanackovic 2010; Brazao 2009; McClelland 2005; Live-in Caregiver Program 2009). In contrast, the settlement experiences of these immigrants after the fact are not as widely studied. The numbers and demographic composition of this group, increasingly derived from the Philippines, reflect a recruitment base that often faces a highly discriminatory and stratified labour market when transitioning out of temporary status live-in caregiving work and becoming permanent residents and citizens.

In 2012, there were approximately 170 male permanent residents who had entered Canada under the Live-in Caregiver Program (LCP), the institutionalized means of recruitment of temporary foreign domestic workers, compared to 3,520 female permanent residents in the same category and year (CIC 2012a, 8-10). Since 1992, a majority of these women have come from the Philippines, with around 8,312 entering Canada in 2008 (Chowdhury and Gutman 2012, 219). The Philippines has consistently provided and even promoted its nationals as overseas foreign workers (OFWs), which rationalizes their significant presence in global labour markets. 
Filipino women are especially prominent in domestic work positions worldwide (Chin 2005; Cristaldi and Darden 2011; Lan 2003).

As late as last year, Citizenship and Immigration Canada (2013) released a news statement anticipating an increased admittance of 17,500 permanent residents in 2014 , almost double the amount of 2013 admissions, through the LCP. Preliminary tables released this year (CIC 2014) outline that the number of permanent residents admitted under the program in 2013 totalled 8,784 individuals. These reports point to both the Philippine and Canadian governments' acknowledgement of the presence and significance of the Filipino female demographic as well as showcase the endurance of the demand for domestic employees. As CIC Minister Chris Alexander stated, "Live-in caregivers participating in the program came here with the promise of permanent residency after meeting work obligations in looking after the children, elderly or disabled people in their care. We need to honour our commitment to them" (CIC 2013b). A majority of the Filipino women who come to Canada as caregivers migrate not only for the purpose of employment, but also with the goal of permanent settlement and reunification with their families. While programs like the LCP or its predecessor, the Foreign Domestic Movement (FDM) help them temporarily achieve the former economic motivation, the limiting provisions of these programs also slow down or hinder their achievement of the latter social aspiration.

Such distinctly racialized and gendered immigration programs as the FDM and LCP tend to evaluate the socio-economic outcomes of immigrant entrants through a cultured and essentialist lens. That is, the criteria for an individual's successful integration into the larger society include the ability to conform to the dominant structures of a class hierarchy. Level of education is often manifested in employment as a determinant of an individual's qualifications and ability to contribute to the society and economy. However, when education and experience 
are demarcated by social constructs like race or gender, one's socio-economic class and position in the hierarchy becomes socially, instead of objectively, determined. The notion of success and thereby belonging in society can then be interpreted in different and conflicting ways. An analysis of the existing literature reveals recurring themes of precarious status, the influence of transnational social networks and individual agency in Filipino immigrants' negotiation and compromise of belonging. Yet, while the ethno-cultural composition of immigrant caregivers has shifted over time, the overall perception of these workers and the occupation itself has showed little change. Only through recognizing and acknowledging the intersectionality of these social constructs and the multiple forms of capital at an individual's disposal—cultural, social, economic — can we reach a more nuanced understanding of the settlement and integration outcomes of Filipina immigrants in Canada. 


\section{Chapter 2}

\section{Literature Review}

\subsection{A Brief History of Domestic Work in Canada}

Race and gender have been enduring and prevalent characteristics of domestic work since the establishment of British North America. Sedef Arat-Koç (1997), for instance, traces the ideological shift of domestic workers from the preferred British "mothers of the nation" to temporary foreign ("coloured") labourers. Prior to and at the turn of the twentieth century, British women were considered the morally superior "civilizers" and nation-builders of the newly developing Canadian nation. They therefore enjoyed a privileged position in comparison to more contemporary domestics of other racial or ethnic backgrounds (65). Especially within an atmosphere of predominantly male British settlers, the role of morally and racially superior women was significant to establishing respectable families and thereby a respectable nation. However, the poor remuneration, working conditions, and isolation that characterized domestic work could not encourage enough of these women to keep the post. As a result, women from other European nations— such as Scandinavian countries, Russia, Italy, Greece and Spain —and later "women of colour" - such as Japanese Canadians in the post-war era, and Caribbean women in the 1950s - were recruited in an unsuccessful attempt to meet the demand for care workers in Canada (65-76).

The moral credibility of these "undesirable" immigrant women, notably women from the Caribbean and Jamaica, soon came into question when concerns began to arise surrounding their exploitation of the domestic scheme as a means of family reunification (Arat-Koç 1997, 75-76; 
Bakan and Stasiulis 1997, 33-34). Immigration officials had assumed Caribbean women would inherently face discrimination in the larger Canadian labour market and would therefore remain in domestic work beyond their one year contracts. This would prove only partly true as these women did indeed face difficulty in the labour market but in spite of that, there were high turnover rates out of domestic service. Adding to this the threat of sponsored family members who were seen to merely contribute to the social problems associated with the economic instability of this ethnic group, the usefulness of the Caribbean domestic scheme lasted only until 1967 with the installment of the points system (Arat-Koç 1997, 75-76; Bakan and Stasiulis 1997, 33-34).

What ultimately developed from this struggle to retain workers in the domestic service sector were the restrictive policies of the 1982 Foreign Domestic Movement and its successor, the 1992 Live-in Caregiver Program that removed the immediate landed immigrant status, previously granted to migrants entering as domestic workers, and established instead temporary work contracts that bound individuals to a single employer. The practice of granting temporary rather than landed immigrant or permanent resident (PR) status to new arrivals employed as domestics or care workers was already in place since 1973 with the introduction of the Temporary Employment Authorization Program. As Bakan and Stasiulis $(1997,34)$ point out, many European domestics continued to enter Canada as landed immigrants in the 1970s whereas an increased number of Caribbean domestics were granted temporary work visas. Significant authority and discretion was placed on the state and employer in terms of immigrants' employment rights and treatment.

In terms of the FDM and LCP, the opportunity to gain landed immigrant or permanent resident status, and thereby the right to enter into alternative forms of employment, became 
conditional on the worker's ability to fulfill the respective program's requirements. Under the FDM, immigrants were required to complete 2 years of live-in domestic employment as well as demonstrate "self-sufficiency" by providing proofs of skill upgrading, volunteer work and financial stability — including the ability to support potential dependant family members (Bakan and Stasiulis 1997, 35; Macklin1994, 18-19). Under the LCP, a program that continues to this day under Canada's Temporary Foreign Worker Program, immigrants have four years to complete either 24 months of authorized full-time live-in employment caring for children under 18 years of age, elderly persons 65 years of age or older, or persons with disabilities; or 3,900 hours in the same authorized employment within at least 22 months to be eligible to apply for permanent residency. A distinct difference between these two programs, however, is the omission of the "self-sufficiency" provisions for PR applicants from the LCP, an adjustment arguably reflective of a more liberalized state since the existence of immigrants' dependant family members is no longer a main concern (CIC 2012b; ESDC 2014).

A further rationalization for the incorporation of temporary work permits in the FDM and LCP grew out of a 1960's liberalizing environment of anti-racism ideals that removed provisions of "preferred countries" from Canadian immigration legislation. This view culminated in the 1967 institution of the points system that did not explicitly consider the country of birth or origin of incoming migrants, but rather, evaluated applicants based on Canada's labour market conditions (Kelley and Trebilcock 2010, Chapter 9). As a subsection of the 1962 regulations leading up to the point system stated, an individual should be admitted to Canada " who by reason of his education, training, skills or other special qualifications is likely to be able to establish himself successfully in Canada' and has either sufficient means to support himself or has secured employment” (Kelley and Trebilcock 2010, 332). Settlement prospects for 
immigrants in Canada were thus expanded as individuals were now purportedly eligible to enter the country based on an indiscriminate evaluation of their own skills and merits.

Taken at its word, this principle of relative equality is reflected in the FDM and LCP since their prerequisites for entry hinge not on a person's country of origin or birth but rather on one's education, relevant skills or experience. For example, under the FDM, applicants had to possess a certificate from a formal school offering training programs in domestic work or a minimum of one year's full-time experience as domestic workers (Macklin 1994, 18). This experience provision was carried over to the LCP as qualified entrants must possess either the one year minimum employment experience or 6 months of full-time training in addition to having the equivalent of a Canadian grade 12 high school education (ESDC 2014). However, this inclusive ideal does not extend far, according to authors such as Bakan and Stasiulis $(1997,32)$ who state:

Because of the popular purchase of racist and sexist assumptions shaping dominant notions of who is and who is not legitimately a Canadian, however, which is consistent with the 'nation-building' ideology of earlier decades, what is unacceptable for most was rendered acceptable for designated 'others,' notably non-citizen women of colour.

Racialized and gendered understandings of belonging and what it means to be Canadian, coupled with neoliberal cut backs on social assistance programs such as day care and housing services, continue to shape the experiences and overall societal perceptions of domestic workers or caregivers today (Arat-Koç 1999, 32-34). The isolation, long hours, poor remuneration and lack of regulation associated with domestic work in the private sphere of employers' homes are conditions deemed unacceptable by most Canadians but are largely borne by immigrant women or "others" that directly contradict the liberal and anti-racist ideals of the 1960s. Arat-Koç (1997) further argues that the FDM and LCP merely institutionalize the racialized and gendered oppression of immigrant women under a veil of liberalization and equality: "Because the 
definitions of 'skill' and 'education' in modern capitalist society approach domestic work as an unskilled and 'naturally' feminine type of work, domestic workers have been unable to qualify under the point system as independent immigrants." She further maintains that immigration authorities "deliberately and arbitrarily lowered the points awarded to domestic servants" in order to achieve this end (77). This feminist perspective maintains that the invisible nature of domestic work as women's work naturally disadvantages and consigns immigrant women to an underprivileged and exploited status. "Gender" becomes synonymous with "class" and "race," and reproduces the nationalist or imperialist standpoint of nineteenth century British North America. Supporting this view arguably relegates immigrant women to the roles of mere victims of patriarchal state policy and neglects their subjectivity as agents of their own narrative stories. This paper seeks to consider this missing perspective through an evaluation of the settlement and integration outcomes of Filipina immigrant caregivers in Toronto.

\subsection{Implications of Foreign Domestic Movement and Live-in Caregiver Program Policies}

The nature of the Foreign Domestic Movement and the Live-in Caregiver Program, as an institutionalized means of commodification of female immigrant labour, inherently launched the highly charged and controversial studies undertaken in the late 80 s and early 90 s. However, rather than focusing on mere social or gendered determinants of difference, contemporary scholars have shifted their analyses to additional political and economic explanations of inequality. Fundamentally, the temporary status, one employer restriction, and live-in requirements of the FDM and LCP underline and legitimize immigrant caregivers' precarious status through collaboration between public policy or the state, and gendered imperatives of 
belonging (Arat-Koç and Giles 1997; Bonifacio 2008; Lee and Johnstone 2013; Solomon 2009; and Stasiulis and Bakan 2005). The traditional notion of women's social reproductive role in the private sphere, and men's influence over policy development in the public sphere assumes that a live-in caregiver-who is theoretically on-call 24 hours a day by virtue of her accommodations - is essentially a member of the family which thus exacerbates the opportunity for her exploitation (Bakan \& Stasiulis 1997, 10). It is also difficult for these women to seek alternative forms of employment given the four to five month waiting period for work permit renewals. In the event that a domestic worker decides to leave or is forced to leave her employer, she must wait for a new permit before she is allowed to begin working for a new employer. This endangers the woman's status in Canada by further delaying her completion of the LCP requirements within the time limit (Bricker and Straehle 2010, 314; Chowdury and Gutman 2012, 227-228).

Studies examining the transition process from temporary worker to permanent resident also identified a trend of long wait times. According to Spitzer and Torres (2008, 18-19), upon completing the requisite 22 months or 3,900 hours of live-in employment for the LCP, some respondents reported waiting upwards of six months or more to obtain their open work visas and a further wait of six to twelve months for permanent residency. Since the changes in LCP policy enacted in 2010 and 2011 that began the concurrent processing of permanent resident and family sponsorship applications, this process could be extended or stalled by the requirement of sponsored family members to pass criminal screenings and medical examinations prior to being admitted to Canada (Chowdhury and Gutman 2012, 218; CIC 2012b). Filipina caregivers' statuses thus become linked to those of their family members back home irrespective of their economic contributions up to this point. For example, the PR application for Yolanda, a Filipina 
domestic worker, was denied because her son, whom she was sponsoring from the Philippines, failed the medical examination (Kapiga 2009, 68). As a result of these delays, many women are stuck in live-in situations since they are not legally allowed to find alternative work until they obtain an open work permit. Additionally, their abilities to regain a socio-economic status equivalent to that they held in the Philippines or other countries are also checked by the inadmissibility of many immigrants with non-PR status to access or utilize public settlement services or enrol in post-secondary institutions. When caregivers are able to take advantage of the public programs available to them, the assistance or services they receive can be overshadowed by the programs' long waiting lists or, in the case of toll free telephone information services, the delayed responses or complicated instructions provided by automated answering machines (Bonifacio 2008, 40; Brickner and Straehle 2010, 316; Spitzer and Torres 2008, 19). A perspective that is missing from these studies, however, is a comparative analysis of the processing times between the FDM and LCP. These studies took place at the turn of the $21^{\text {st }}$ century and focus largely on the processing times of entrants under the Live-in Caregiver Program. While it is beyond the resources of this study, the extent, if any, to which these times have evolved between programs and the resulting impact on Filipina women's ability to settle in Canada would be interesting to examine.

Given the above complaints, the degree of information dissemination, access and relevance of public settlement services becomes a prominent issue. Participants in a 2012 Ontario-wide study concerning immigrant and refugee use of settlement and integration services revealed that more than half of the participants who did not use any government settlement support services turned to alternative networks of family (48.4\%) or friends (32.3\%). Otherwise, $29.9 \%$ claimed they had no knowledge of the available services or had difficulty in accessing 
them due to a lack of transportation $(22.8 \%)$ or the services' inconvenient hours of operation (8.5\%) (OCASI 2012, 66-67). For Filipino women coming out of the FDM or the LCP, the services offered by public government-funded organizations are largely seen as irrelevant due to their focus on English or French language proficiency or translation, and the inconvenient operating hours that usually finds them busy at their live-in caregiving occupations, if they have not yet received their open work permits. Their eligibility to utilize these services is also restricted by the number of years spent in Canada. Targeted towards permanent residents within their first two years of arrival, the time constraints of programs like the FDM or LCP prevent many Filipino women from profiting from these forms of assistance since they can spend upwards of 2 years in temporary status live-in employment. Informal networks of family and friends and formal Filipino associations and faith-based communities, are therefore regarded as the more practical and immediate routes to gaining the necessary employment, housing and financial support these women seek (Bonifacio 2008, 34-36; Bonifacio 2009, 138; McKay 2002, 25).

Another source of vulnerability for Filipina caregivers is derived from the economic or capitalist driven power struggles that underpin women's work in general. As Canadian womenwho are entering the labour market in increasing numbers — struggle to balance home and work responsibilities, immigrant Filipino women are brought in as replacement social reproductive labour. Middle-men recruitment and placement agencies then take advantage of this gendered imbalance of work inside and outside the home. For instance, a 2010 documentary titled The Nanny Business exposed the "business," akin to human trafficking, of enticing women from the Philippines to come to Canada as live-in caregivers. Many agencies charged Filipinas exorbitant and illegal fees for their placement services yet once these women arrived in Canada, some 
found that their employer/sponsor was merely a fabrication and that they were stranded in the country with no way of supporting themselves.

According to Stasiulis and Bakan $(2005,13)$ " [...] nation-states remain the most important governance site for the allocation and regulation of citizenship rights, responsibilities

and burdens." However, since the nation-state distinguishes between temporary foreign workers and permanent residents or citizens, their enforcement of rights and labour regulations for the former is severely lax. This "global citizenship divide" distinguishes between those belonging to the "global North" (developed nations), and therefore deserving of citizenship rights, and those coming from the "global South" (lesser developed nations) and underserving of these same rights (25). However, while the nation-state, acting in the interests of labour markets, deliberately undermines the interests of immigrant domestic workers, the reactions of individual immigrants and their networks of social capital should not be discounted and can play an equally influential role in their settlement and integration experiences and outcomes.

\subsection{Economic Barriers of Deskilling and Credential Non-Recognition}

One of the most prolific disadvantages of the Foreign Domestic Movement and the Livein Caregiver Program is the progressive deskilling of the immigrants that results from long years in the caregiving occupation. This trend is exacerbated by the Canadian provinces' refusal to recognize their foreign credentials despite the contradictory education or experience, and language requisites necessary to entering the programs (Chowdhury and Gutman 2012; Engelhart 2010, par. 5; Martin Spiegelman Research Associates 2000, 18; McKay 2002, 25; Spitzer and Torres 2008, 20). Several studies have emphasized the significant proportion of 
highly educated women from the Philippines coming to Canada under the LCP (Chowdhury and Gutman 2012, 223; Kapiga 2009, 60; Miller 2010, 44). Yet, as Brickner and Straehle $(2010,310)$ point out, "[ [...] policy makers consider the LCP only in terms of work legislation and as a path to membership for migrant workers thus thinking of it only in terms of immigrant policy." This perspective presents a shallow view of the migration process of women from the Philippines.

Viewing the LCP merely in terms of work legislation considers only the first aspect of immigrants' transnational movement: the initial entry into Canada. Understanding that the end goal for many Filipina live-in caregivers upon entering Canada is settlement within the larger society is only one aspect of what Spitzer and Torres (2008) called a "two-tier system." Essentially, immigrant women coming out of live-in caregiving work undergo a "second transition" that involves repetitive procedures of "filing applications, locating employment and housing, and expanding social networks" (18-19). Although these are all procedures already experienced during the initial immigration process, structural contradictions prolong and prevent a smooth transition from temporary worker to permanent resident and citizen as was examined in the previous section. There is an assumption that once an immigrant is accepted into the country via the FDM or LCP, her path to permanent residency is set. However, the "two-tier system" shows that there are other economic and social aspects to the settlement process that are perpetually being negotiated.

Another implication of the deskilling and the rejection of the educational credentials of Filipina immigrants on their post-FDM and post-LCP settlement experiences is the tendency of these women to remain in similarly low-skilled and low-wage occupations such as cashiers, babysitters, cleaners, live-out or live-in caregivers. This economic aspect of the "two-tier system" comes out of structural barriers that prevent immigrant domestic workers from the Philippines 
from realizing their employment potential, a consequence which could hinder or discourage the goal of citizenship espoused upon initial entry (Kelly 2007, 216; HRSDC 2013, Table 7 \& Table 12; Spitzer and Torres 2008, 20). A Quebec study on the socio-professional or socio-economic integration of live-in caregivers by Castonguay and Benzakour $(2010,43)$ revealed for example, that $57.3 \%$ of the 312 former caregivers they surveyed between 2000 and 2004 had found employment outside of caregiving. However, the majority of these included personal support work or health care positions that demanded similar domestic tasks. The continual fallback to domestic duties does not require a significant degree of educational training nor does it denote a significant degree of prestige or respect. As a result, sentiments of dissatisfaction or discouragement are often highlighted in several narrative examinations of Filipina caregivers in Canada such as the qualitative narratives in Kapiga's (2009) work.

A solution to the issue of deskilling and unrecognized foreign credentials taken up by Filipina caregivers involved volunteering at community organizations or with advocacy groups in order to give back to the community and gain official Canadian experience. For instance, PINAY, the Filipino Women's Association in Quebec, provided caregivers both entering and leaving the LCP with housing, employment, fundraising and activism services. Miller $(2010,61)$ cites Thelma C. de Jesus, the organization's founder, who argues that PINAY and other self-help groups emerged to "fill the vacuum, providing services to meet the needs of Filipinos which should be provided by the state." The inability of the state to sufficiently uphold the labour rights of or provide for Filipina domestic workers problematizes, once again, its authority and motivations. 


\subsection{Social Networks' Push to Uphold Economic and Cultural Obligations}

The pressures placed on immigrant women to support their families back home while maintaining proper cultural behaviours and values disadvantage them as workers and as an ethnic group. In their surveys of 13 female and 1 male Filipino caregiver in 2009 and 2011, Chowdhury and Gutman (2012) underlined the limitations of relying on networks of family and friends. In response to the question "If you had the chance to do things over, would you come to Canada under the LCP?" several respondents claimed that: "If they had known beforehand that as a college graduate and person with a professional background, they could apply for Canadian immigration under 'skilled immigrant' and other professional immigrant categories, they would have chosen those paths to enter Canada, instead of the LCP" (228). This lack of knowledge of the Canadian immigration system can set back the settlement goals of Filipina caregivers by years, especially in light of the significant wait times and potential delays of the transition experience and notwithstanding their two year minimum tenure as live-in caregivers. It is arguably linked to the Philippine state's emphasis on labour export, namely the export of female caregivers, and the capitalization of this strategy by Filipino families in order to generate remittances back home (Bonifacio 2008, 28; Martin Spiegelman Research Associates 2000, 18; McKay 2002, 30; Pratt 2003, 10-12; Stasiulis and Bakan 2005, Chapter 3).

The Philippines' labour export policy was responsible for approximately $\$ 12.8$ billion in remittances being sent to the Philippines in 2006, equal to $10 \%$ of the country's gross domestic product (GDP) (Bonifacio 2008, 28). In 2007, $\$ 14$ billion in remittances sent by OFWs accounted for $10 \%$ of the country's GDP (Solomon 2009, 290). For their efforts, OFWs are praised for their roles as bagong bayani or "new heroes" (Bonifacio 2008, 28; Solomon 2009, 
289; Stasiulis and Bakan 2005, 103). A news release published by the Philippine Overseas Employment Administration (2011) honours these workers' contributions through the Bagong Bayani Awards:

The Bagong Bayani Awards (BBA) is a private sector-led national search for the country's outstanding and exemplary Overseas Filipino Workers. It seeks to recognize and pay tribute to our OFWs for their significant efforts in fostering goodwill among peoples of the world, enhancing and promoting the image of the Filipino as a competent, responsible and dignified worker, and for greatly contributing to the socio-economic development of their communities, and our country.

In Canada as well, the financial support provided by Romelyn Saneo, a Filipina caregiver in Thornhill, Ontario, was commended in a CBC broadcast (2013) following the destruction of Typhoon Haiyan that struck the Philippines in 2013. The money she sent back to her family in Bantigue, Philippines enabled them to build a home that was able to withstand the floods, saving the lives of not only her family but also that of some 100 other villagers who sought shelter on the second storey of the house. In both cases, as Kelly and Lusis (2006, 843-844) point out, a euphemistic valuation associates the term "abroad" with Filipina immigrants having "made it" or having successfully escaped the poverty and subservience of the home country through employment, and eventually settlement, abroad.

However, the pressure to be the primary breadwinners and embody behaviours of the "good daughter" can escalate into feelings of indebtedness for Filipina domestic workers. This "debt of gratitude" or utang na loob implies a commensurate economic return to the social and economic support provided by the family prior to migration (Betsayda 2008, 36; Bonifacio 2009, 138-139). The implication of these socio-cultural and economic responsibilities on the post-livein settlement outcomes of Filipina immigrants in Canada is their resulting inability to afford, or lack of desire to pursue skills upgrading or post-secondary courses to reclaim the status, skills and credentials lost upon immigration (Pratt 2003,11). This outcome relates to the 
aforementioned structural policy constraints that restricted the employment choices of post-FDM and post-LCP women. The unrecognized credentials of immigrants from the Philippines, the “invisibilization" of women's care work (Arat-Koç 2012) and the requirement of Canadian work experience frustrates Filipina domestic workers' attempts to balance familial obligations, employment, and desires for upward socio-economic mobility.

As opposed to the positive appraisal of Filipina caregivers' financial contributions to the Philippine state and their families, Canadian citizens, including other Philippine nationals, tend to endorse a "double isolation" of this group that "contributes to their experiences of being 'career domestics"” (McKay 2002, 25). By virtue of their occupation, immigrant women who initially enter Canada under the LCP are "looked down upon" even after they have freed themselves from the constraints of live-in work (Martin Spiegelman 2000, 18; Pratt and PWC 2003, 9). This stigma therefore entrenches gendered and classed biases of service work within notions of the ethnic group itself which have negative implications for the social capital diversity of these women. Filipinas are essentialized as "naturally domestic," thus normalizing their role as caregivers and by extension, preserving their "preferred" place in other service sector jobs (Macklin 1994, 21-22). As McKay $(2002,26)$ and Kelly $(2007,230)$ argue, the "complex ambivalence that many in the [Filipino] community feel toward their caregiver compatriots" encourages marginalization out of fear and resentment "that all Filipinos should be tarred with the same brush."

The classed and racialized subordination of Filipinas is also normalized within the domestic profession itself. As a German nanny remarked in England and Stiell's $(1997,211)$ study:

I don't know why employers pick nannies of different nationalities, but I know mine picked me and not a Filipino because they didn't want [the children] picking up on the 
foreign accent. Although I have an accent too, it is not as huge or whatever, as strong [...] They also wanted someone who will put their foot down with the kids, because they [Filipinos] can't [...] Filipino girls are all being treated more like a little sister, a family member. They fear the day she leaves, they depend on her so much [...].

According to this statement, McKay's "double isolation" could arguably be extended to a "triple isolation" of Filipina caregivers by Canadian citizens or the state, the Filipino community, and other immigrant caregivers of different ethnic origins. A recent news article published in the Toronto Star (Keung 2014) similarly revisits the controversy surrounding Caribbean domestic workers' family sponsorship in the 1950s and applies it to Filipina caregivers today. The Canadian government fears that Filipina caregivers are exploiting an "out of control" or "mutated" LCP as a primary a means of family reunification. This in turn is calling into question the merit of naturalizing these women. Alternatively, a national statement released by the Philippine Women Centre-Ontario (2014) inverts the "mutated" rhetoric and accuses the state of exploitation in pursuit of capitalist gain:

As part of its overhaul of the Temporary Foreign Workers Program (TFWP) two months ago, the Conservative government already changed the LCP application fee from $\$ 275$ to $\$ 1000$. This change alone demonstrates that the Canadian immigration system has really 'mutated' into a profit-driven enterprise.

These statements reveal the ongoing power struggle between contradicting social and economic imperatives of the state, both Canadian and Philippine, social networks, and individual immigrant caregivers as they attempt to establish an equal place for themselves in Canada. Overall, the social capital available to post-FDM and post-LCP Filipino women are impacted by these imposed isolations and can result in a homogenized networking pool of other former caregivers who provide limited information on other occupational prospects (McKay 2002, 2627). Class, along with race and gender, therefore continue to impact the perception and treatment of immigrant caregivers that echo nation building ideologies of the $19^{\text {th }}$ and $20^{\text {th }}$ centuries. 
However, it is important not to essentialize the behaviours of Filipina immigrants that merely contribute to the normalization of their presence as domestic workers or caregivers. Filipino women's roles as family members, national saviours and workers are not separate and distinct identities but the often blurred and complicated results of state policies, social objectives and individual and subjective agency.

\subsection{Construction and Re-construction of Social and Economic Identity}

The ways in which Filipino women construct and reconstruct their individual and collective identities in Canada are simultaneously influenced by the structural policies of the Canadian nation-state and its nation-building ideologies, as well as by the socio-cultural and socio-economic expectations of their social networks and the Philippine nation-state. According to Macklin $(1994,32)$ the role and designation of the "foreign domestic worker" is anachronistic as the women who embody this title are considered as doubly outsiders yet entrenched emotionally and physically in Canadian society. Also, they are called workers yet their labour is invisible to the larger society so long as they are unregulated and confined to the home. These contradictions challenge feminist contentions that women are increasingly exercising their citizenship privileges to "buy [their] way out of sex oppression" by increasingly participating in the larger Canadian labour market (Macklin, 1994, 34), a view that neglects the presence of female foreign workers in domestic positions.

In spite of these contradictions, narrative studies by scholars have found no drastic change in the societal perception of domestic work as women's work (England and Stiell 1997; Guevarra 2003; Kelly 2007; McKay 2002; McKay 2003). Outside of Canada as well, this socio- 
economic gendered hierarchy is not easily changed. Lan's (2003) study on Filipina domestic workers in Taiwan found that the women gained autonomy and authority within their households back home as the main breadwinners. In some cases, this led to a reversal of gender roles in the family as husbands left behind became the "domesticated housebands" or "huswives" (193). However, this change is relatively rare as the gendered gaze imposed on these women, their status, and their occupation also criticizes their sexuality. While they are considered the breadwinners of their families and heroes in their home country, the Canadian state and society shows hostility towards their family reunification (Keung 2014). The majority of studies on the transnational Filipino family focus on family separation and reunification, often after an interval of many years, while the mother or wife struggles to obtain permanent residency in order to sponsor her family to come to Canada. A consequence of this separation is the alienation of the wife from her husband or the mother from her children (Bakan and Stasiulis 1997, Cabanes and Acedera 2012; Cohen 2000; De Leon 2009; Kapiga 2009; Lan 2003, 193; Macklin 1994; Pratt 2006).

A study of Asian transnational domestic workers in Malaysia notes a similar opinion. Since the 1980s, a polarized view among Malay employers regarding Filipina live-in caregivers has dictated that, "Although Filipinas may be considered more socially desirable by employers because of their command of the English language and their knowledge of modern utilities involved in housework, they also are considered more 'uncontrollable' than Indonesian women" (Chin 2005, 269). The perceived promiscuity of Filipino women has translated to a minimum age restriction of 30 years for entry as live-in caregivers, as opposed to the 18 year age limit for Indonesian women. 
Stereotypes that were racially ascribed to Filipina women in the late 1980s and early 1990s are still being referred to today and are social attributes that should be problematized. As mentioned in the previous section, Macklin $(1994,22)$ and England and Stiell $(1997,209)$ critique the racialized titles of domestic workers. Where a white, middle-class, British woman would be addressed as a "nanny," a coloured woman from the global South would be addressed as a "caregiver" or "domestic." The type of language used to describe an individual or group significantly influences the construction of identity. In stark contrast to the Malaysian case, Filipina domestics in Canada, for example, were preferred by some employers because they were seen as loving, nurturing, clean, and quiet (Macklin 1994, 22). From a feminist perspective, these views underline characteristics that are ultimately used to justify the subordinate treatment and exploitation of foreign domestic workers and the domestic occupation in general since Filipino women are seen to fit perfectly into the role of subservient and submissive workers who require no supervision.

On the other hand, some studies have emphasized the relative upward social mobility granted to these migrant women as individual wage earners and family breadwinners (Chowdury and Gutman 2012; Kapiga 2009). Isabelle Kapiga's (2009) interviews with current and former Filipina live-in caregivers mentioned various incentives the women had to remain in Canada. Among them, Canada's system of naturalization and the ability to sponsor family members were the most appealing, as well as the opportunity for earning a higher wage (62). Chowdury and Gutman's (2012) longitudinal survey of 14 LCP long-term/elderly caregivers in 2009 and 2011 found that in 2009, 6 out of 14 participants answered "yes" to the question that if they could start over, they would come to Canada again under the LCP. These individuals cited a personal reward in "helping others," and "self-improvement" among their explanations (226). In 2011, 
although only 3 out of the initial 14 participants could be contacted, all stated they were currently employed full-time -2 had gained permanent resident status, 1 had an open work permit—and enjoying an improved income, professional options and an overall optimism for the future, albeit 2 were still engaged in caregiving work (232-235). For these individuals, satisfactory settlement into Canadian society did not solely depend on finding employment commensurate to their education or credentials so much as reaping the benefits of citizenship in the form of family reunification and greater educational and employment opportunities for their children. These ends were considered worth the risks of separation and degradation that entailed their method of entry into Canada.

The sources I have reviewed above displayed minor shifts in perspective since the late 1980s and early 1990s, yet the overall impression of Filipina live-in caregivers still remains grounded in gendered, racialized and class based ideals of neoliberalism and capitalism. It is for this reason that works thought of and contrived in the previous two decades are still relevant and applicable in today's society. Further in-depth studies that consider these intersectional constructs and imposed inequalities, and the forms of capital strategically used by individuals to cope with them therefore need to be conducted on immigrant Filipino women's experience as permanent residents and Canadian citizens in order to fully appreciate their migration experiences. An ongoing and innovative example is the Gabriela Transitions Experience Survey (GATES), a joint research initiative between Gabriela Ontario, York University and Ryerson University that examines the settlement and transition experiences of a Canada-wide sampling of more than 600 Filipina former live-in caregivers (GATES 2014). 


\section{Chapter 3}

\section{Theoretical Framework and Research Questions: Intersectionality and Forms of Capital}

This study involves a qualitative narrative inquiry of the settlement and integration experiences of Filipina participants who entered Canada under the Foreign Domestic Movement and the Live-in Caregiver Program. The socio-political and socio-economic impacts of the programs' policies will be juxtaposed against mutually constructed social concepts that perpetuate the vulnerability and subordination of the participants such as gender, race or class. While scholars like Patricia Hill Collins (1998) have examined how traditional "family values" embody these intersectional "systems of oppression" (63), the focus of this paper will not only elaborate on the role of the family as part of immigrants' social capital, but also on the influence of other forms of capital on the expression of individual agency. These different forms of capital, coined by Pierre Bourdieu, include: economic capital, monetary possessions; cultural capital, “embodied" behavioural markers, "objectified" material symbols, and "institutionalized" educational qualifications; and social capital, one's strategic networks or group membership (Bourdieu 1986; Kelly and Lusis 2006, 833-836). According to Bourdieu:

Capital is accumulated labor (in its materialized form or its 'incorporated,' embodied form) which, when appropriated on a private, i.e., exclusive, basis by agents or groups of agents, enables them to appropriate social energy in the form of reified or living labor [...] And the structure of the distribution of the different types and subtypes of capital at a given moment in time represents the immanent structure of the social world, i.e., the set of constraints, inscribed in the very reality of that world, which govern its functioning in a durable way, determining the chances of success for practices (46).

The ways in which individual Filipino immigrant women valorize and invest their embodied or objectified capital resources, or the behavioural and material markers that socially identify them, is indicative of their ability to carve a place for themselves within the established hierarchy of 
Canadian society. While the different strategies of accumulating and distributing capital can be converted to economic profit, they ultimately serve to reproduce the social class and power relations already in place (Bourdieu 1986, 54). However, understanding that the negotiation of settlement and integration is a conscious act of agents also acknowledges the diversity and subjectivity of immigrants' experiences that may not conform to the above claim. Uma Narayan's (2000) criticism of a "package picture of cultures" espouses this viewpoint as she argues against essentialist notions that cultures are "neatly wrapped packages, sealed off from each other, possessing sharply defined edges or contours, and having distinct contents that differ from those of other "cultural packages"” (1084). In order to avoid essentializing the immigration and settlement cases of the Filipina participants, an emphasis will be placed on their subjective voices and individual authority.

An inductive enquiry approach utilizing semi-structured interview questions will attempt to position the unique experiences of Filipina immigrants in Toronto within the larger macro and micro-level social constructs. The goal will be to explore the connections between their empirical experiences during their time in the LCP or its predecessor, the FDM, and their experiences of settlement and integration in the larger society following the completion of these programs. Specific research questions that will be addressed include:

- In what way are social and cultural capital resources utilized and valorized by Filipina immigrants in negotiating their settlement in Canadian society?

- How do Filipina immigrants view satisfactory settlement in Canada? Do their understandings conform to an existing social hierarchy?

- Do their settlement experiences and overall satisfaction differ depending on the immigration program under which they enter Canada? 
- How do the policies of the FDM or LCP impact the ability of immigrant women from the Philippines to successfully integrate into Canadian society?

- Where do Filipina immigrants find the most support during their transition period?

- What types of employment do these women do post-FDM or post-LCP? Why?

In light of the prolific literature, both academic and public, examined above, I would posit that the barriers or obstacles to settlement in Canada and the resulting levels of satisfaction of the participants would not vastly differ between entry under the Foreign Domestic Movement or the Live-in Caregiver Program as decades of analysis since their inception have shown very minimal variation. What will be most significant to note is the role and application of the different forms of capital on expressions of individual agency in response to the perceived oppressions of the larger Canadian state and society. 


\section{Chapter 4:}

\section{Methodology}

\subsection{Positionality and Paradigm: Hybrid Insider-Outsider}

According to Carling, Erdal and Ezzati (2013, 2), positionality, or the researcher's characteristics, substantively and practically impacts the research process: "from the nature of the questions that are asked, through data collection, analysis and writing, to how findings are received." In referring to their coined "insider-outsider divide," the authors highlight shared ethnicity as one marker of a researcher's membership within the migrant group under study (“insider status") or conversely, their lack of membership (“outsider status"). They argue, "Just as we should not conflate nation states with societies, we should not uncritically accept ethnonational distinctions as the primary group boundaries in migration processes. Whether and how these distinctions are important is an empirical question" (3).

My own position within the immigrant group under study can be considered what the authors coin a "hybrid insider-outsider" (16). Both of my parents are natives of the Philippines who immigrated to Canada in the early 1980s. I can trace the migratory flow of my extended family; the majority of who also currently reside in Canada, from my own mother who entered Canada first as a live-in caregiver and who subsequently sponsored siblings in the Philippines to immigrate. This association provides me with privileged "insider" cultural skills and values that are easily identifiable with the subject group of this project.

However, being born and raised in Canada and having learned to read, write and speak English and French rather than Tagalog or Ilocano (a Filipino dialect) has limited my ability to 
communicate with those with whom I share a cultural and ideological, if not national, origin and entrenched me within the "outsider" divide of migration research. I have not yet even had the opportunity to visit the Philippines, a fact that I sincerely regret and strive to redress in the hopefully near future. Yet, this desire in itself provides a motivation for this research topic. Having not experienced the cases of live-in caregiving and transition first hand, the examination of Filipino women's immigration narratives provides an enlightening perspective on my own historical and cultural background.

Other elements of shared social identity outside of ethno-national origin or language can likewise impact the researcher-informant relationship. Gender, physical appearance, cultural competence - the "shared interpretation of codes and context-specific behavioural norms" —or religion are also relevant and telling positional markers that can influence what and how much informants or interviewees choose to share (Carling, Erdal and Ezzati 2013, 9-13). In her book Narrative Inquiry, Kathleen Wells $(2011,95-97)$ notes that individuals have multiple voices that are manifested through the performance of preferred identities. According to Riessman (2008), quoted in Wells $(2011,7)$, “[...] narrative analysis is useful when the interest is in how and why a story is constructed as it is, what it accomplishes, and how the audience affects what may be told." In examining the personal narratives of Filipina immigrants in Canada, my position provides me with a dual perspective that is able to transcend arguments of mere ethno-national or ethno-cultural causality regarding the issues involved with the settlement and integration of this immigrant group in Canada. In alignment with Carling, Erdal and Ezzati (2013), rather than focusing solely on the ethnic characteristics of the study participants, intersecting constructs of gender, class and race — and the impact of these constructs on their immigration and settlement 
experiences - provide a much more constructive means of evaluating narrative discourse analysis and must be taken into account.

However, it should also be noted that hybrid positioning also poses risks of accentuating rather than fading social-cultural differences such as class, education or migration history (Carling, Erdal and Ezzati 2013, 17). Establishing the validity of narrative research therefore becomes a question of the researcher's selection, presentation and interpretation of the empirical data along these intersectional lines (Wells 2011, 114). This first becomes established in the project's methodology before any analysis of the primary research is conducted.

\subsection{Purposive Sampling and Inductive Enquiry}

Due to the ethnic and racial specificity of my research questions and area of interest, the recruitment of participants for this study involved a purposive sampling of immigrants from the Philippines, all female, who had entered Canada as live-in caregivers under the Foreign Domestic Movement or the Live-in Caregiver Program. Participants were initially identified through my own personal connections followed by snowball sampling.

In order to avoid impressing my own preconceived notions of this immigrant group, based in part on my positionality within the Filipino community and my previous knowledge of other studies, the format and breakdown of the interview questions were developed through inductive reasoning and enquiry that emphasized a semi-structured interview outline, including both closed and open-ended questions. My analysis relies upon the responses of participants to these questions in order to identify major themes of the immigration and settlement experience. For example, closed-ended questions focused primarily on establishing the demographic 
characteristics of the participants. These types of questions are integral to codifying the data later in terms of gender, class, age or level of education. Open-ended questions, on the other hand, are more general and allow the participant to freely elaborate on or conceal information. Appendix A lists the general questions that were asked. However, other impromptu questions may have been asked throughout the interviews. Due to the personal nature of the information and testimonies being shared, all participant recruitment adhered to strict ethical guidelines.

\subsection{Maintaining Confidentiality}

Similar to Carling, Erdal and Ezzati's (2013) criticisms of positionality within an “insider-outsider divide," researchers must not exploit their "insider" status through exercising "undue influence" on potential participants. As scholars such as McKay (2002, 23-24) and Kelly (2007, 229) have pointed out, a social stigma tends to surround occupations of care or domestic work in Canada. Paid or unpaid, women's work within the home is regarded as low-skilled, menial work that in the Filipino community, can manifest in a "sense of shame," resentment, low self-esteem, or the ambivalence of some women in these types of jobs to recount their experiences. In order to avoid this discomfort, the confidentiality of participants was of the utmost importance. Prior to the start of the interview, they were informed of their right to refuse answering any question with which they feel uncomfortable and of their right to cease participation in the study at any moment during the interview process. Any information obtained in the event of such a cessation was immediately deleted or destroyed and no further contact was made with the individual(s). See Appendix B for the Informed Consent Form distributed to all participants outlining these rights. 
All personal information such as names and places have been intentionally omitted or replaced in this study with a letter of the alphabet while any questions asked by the interviewer have been indicated by the letter "I." The interview process was audio recorded using an audio recording device and responses were supplemented by typed or hand-written notes taken by the researcher throughout the interview. A large majority of the interviews took place over the phone or in the interviewees' private homes at a convenient time for the interviewees. See Appendix C for the telephone script used in the recruitment process. Only the researcher has access to any information gained from participants. All data are kept under lock and key or password protection for the duration of the study and up to one year afterwards. Each interview ranged from 45 minutes to one hour or more, depending on participants' dispositions to elaborate on their experiences. Following each interview, a transcript was typed and made available, upon request, to participants who wished to verify or amend the information provided. The analysis and codification of recurring themes within the data was completed through the use of NVIVO 10 qualitative data analysis software.

\subsection{Study Limitations}

Limited time and resources restricted the sample size of the participants as well as the length of the interviews due to scheduling conflicts. The study is also geographically confined to an analysis of the settlement and integration experiences of Filipinas in the receiving country, specifically Toronto, Canada. While a more comprehensive analysis of transnational settlement patterns and immigrants' social networks is not possible within this study, there is room for expansion in future research. This could also include a triangulation of study findings with elite 
or professional interviews as well as a mixed methods approach that would incorporate comprehensive quantitative data. As a result, this study does not argue generalizability; however, the small sample size is beneficial in terms of obtaining more in-depth and subjective data. All interviews were conducted in English, thus limiting some respondent's ability to elaborate on their answers or experiences. Despite the precautions taken to ensure confidentiality, it must also be reiterated that each participant's responses and stories are presented with a subjective voice; the voice of the narrators that comprise all the silences or performances of "preferred identities" (Wells 2011, 95-97) and the voice of the researcher's own interpretations of these narratives.

\subsection{Study Participants}

Seven Filipino women agreed to participate in this study. They all reside in Toronto and range in age from their mid-30s to early 60s. Four out of the 7 participants entered Canada prior to 1992 under the Foreign Domestic Movement (A, B, C and D), while the remaining 3 participants entered under the Live-in Caregiver Program (E, F and G). Initial interviews took place between June and early July 2014 with follow-up interviews taking place, where possible, in late July 2014. To be eligible for participation in this study, all individuals had to have completed the requirements of either the FDM or the LCP and must currently possess an open work permit, permanent resident status, or Canadian citizenship. Table 1 below outlines the characteristics of each participant in terms of date of arrival in Canada; current immigration status; current occupation; highest level of education completed in the Philippines, along with area of study where applicable; and the types of training or courses completed in Canada. 
Table 1: Outline of Study Participants

\begin{tabular}{|c|c|c|c|c|c|c|}
\hline $\begin{array}{l}\text { Partic } \\
\text { ipants }\end{array}$ & $\begin{array}{l}\text { Date of } \\
\text { Arrival } \\
\text { in } \\
\text { Canada }\end{array}$ & $\begin{array}{l}\text { Program } \\
\text { of Entry }\end{array}$ & $\begin{array}{c}\text { Current } \\
\text { Immigration } \\
\text { Status }\end{array}$ & $\begin{array}{c}\text { Current } \\
\text { Occupation }\end{array}$ & $\begin{array}{l}\text { Highest } \\
\text { Education in } \\
\text { Philippines }\end{array}$ & $\begin{array}{l}\text { Completed } \\
\text { Training in } \\
\text { Canada }\end{array}$ \\
\hline A. & 1981 & FDM & $\begin{array}{l}\text { Dual } \\
\text { Citizenship: } \\
\text { Canada \& } \\
\text { Philippines }\end{array}$ & $\begin{array}{l}\text { Retired } \\
\text { (Former } \\
\text { mailroom } \\
\text { clerk) }\end{array}$ & $\begin{array}{l}\text { Bachelor of } \\
\text { Science \& } \\
\text { Commerce }\end{array}$ & First Aid \\
\hline B. & 1980 & FDM & $\begin{array}{l}\text { Canadian } \\
\text { Citizen }\end{array}$ & $\begin{array}{l}\text { PSW } \\
\text { (Personal } \\
\text { Support } \\
\text { Worker) }\end{array}$ & $\begin{array}{l}\text { High School } \\
\text { Diploma }\end{array}$ & Typing, PSW \\
\hline C. & Feb-87 & FDM & $\begin{array}{l}\text { Canadian } \\
\text { Citizen }\end{array}$ & $\begin{array}{l}\text { PSW } \\
\text { (Personal } \\
\text { Support } \\
\text { Worker) }\end{array}$ & $\begin{array}{l}\text { Bachelor of } \\
\text { Science of } \\
\text { Nutrition and } \\
\text { Dietician } \\
\text { (BSND) }\end{array}$ & PSW \\
\hline D. & 1989 & FDM & $\begin{array}{l}\text { Canadian } \\
\text { Citizen }\end{array}$ & Housekeeper & $\begin{array}{l}\text { High School } \\
\text { Diploma }\end{array}$ & $\begin{array}{l}\text { Typing, } \\
\text { considering } \\
\text { taking PSW } \\
\text { course }\end{array}$ \\
\hline E. & Dec-04 & LCP & $\begin{array}{l}\text { Permanent } \\
\text { Resident }\end{array}$ & $\begin{array}{l}\text { PSW } \\
\text { (Personal } \\
\text { Support } \\
\text { Worker): } \\
\text { Live-in }\end{array}$ & $\begin{array}{l}\text { Bachelor of } \\
\text { Arts (English } \\
\text { Major) }\end{array}$ & $\begin{array}{l}\text { PSW \& Food } \\
\text { Handling }\end{array}$ \\
\hline F. & Oct-08 & LCP & $\begin{array}{l}\text { Permanent } \\
\text { Resident }\end{array}$ & $\begin{array}{l}\text { Medical Lab } \\
\text { Assistant/ } \\
\text { Technician }\end{array}$ & $\begin{array}{l}\text { Bachelor of } \\
\text { Psychology }\end{array}$ & $\begin{array}{l}\text { PSW, Medical } \\
\text { Lab } \\
\text { Assistant/Technic } \\
\text { ian }\end{array}$ \\
\hline G. & Oct-02 & $\mathrm{LCP}$ & $\begin{array}{l}\text { Permanent } \\
\text { Resident }\end{array}$ & $\begin{array}{l}\text { PSW } \\
\text { (Personal } \\
\text { Support } \\
\text { Worker) }\end{array}$ & $\begin{array}{l}\text { Bachelor of } \\
\text { Commerce }\end{array}$ & PSW \\
\hline
\end{tabular}

Among the participants who entered under the FDM, half possessed high school diplomas and half possessed post-secondary degrees while all participants who entered under the LCP completed a post-secondary degree. The geographical limitations of this study prevent a broader pursuit of the potential reasons for this disparity; however, in line with the examined 
literature, these forms of institutionalized cultural capital did not translate into commensurate employment once the participants obtained permanent resident and citizenship status. 5 out of the 7 women are still currently employed in service sector occupations; 1 is a live-out housekeeper or cleaner for various employers while the other 4 are employed as personal support workers (PSWs) in differing capacities. Participants B and C are employed at long-term elderly care facilities in Toronto while participant $\mathrm{G}$ works for a government agency that assigns live-out caregivers to elderly clients in their private homes. Participant E is the only individual out of the 7 who is still involved in live-in caregiving work while participants A and F are no longer employed in domestic work. The former is currently retired, however, she previously worked as a mailroom clerk for a media organization and the latter has recently completed a certificate program as a medical lab assistant and works today at a clinic and a pharmaceutical research company in Toronto.

The disproportionate representation of personal support workers among the employment outcomes of the participants is equally distributed among those who entered under the FDM and those who entered under the LCP. Through an in-depth analysis of their interview responses, the situations and motivations leading up to this employment and their impacts on the overall satisfaction of these women in settling into Canadian society will be addressed. 


\section{Chapter 5:}

\section{Discussion of Participant Narratives}

\subsection{Social Capital and Employment Agencies: Impact on Employment Outcomes}

Once a live-in caregiver has completed the requisite work hours and, in the case of the FDM, undergone a skills upgrading course, she is eligible for landed immigrant or permanent resident status that would allow her to enter into alternative forms of employment and housing arrangements. However, the relative isolation of her accommodations and the unseen or marginalized status of her employment up to this point have meaningfully limited, though not erased, her networking opportunities and work prospects. As one interview respondent described:

B: Starting is the hard part because they have to start to look. They [immigrants] don't come here with a job right away. It's better for those people [with] working permits sometimes. They come here; they have their own employers already. But if you come here [as an] immigrant with nobody, it's going to be hard because you don't have a job right away, you have to look for a place to stay...things like that. So, mostly immigrants are starting with nothing.

In comparison to newcomers who enter Canada without guaranteed employment, the contract and live-in restrictions of the FDM and the LCP can be beneficial during the initial arrival of those who lack pre-established connections in Canada. For Filipina live-in caregivers coming out of these programs, however, the necessity of finding new forms of employment and housing instigates Spitzer and Torres' (2008) previously mentioned "two-tier system.” Post-FDM and post-LCP immigrants' settlement experiences are akin to starting over yet without the complete lack of social capital other newcomers may face. As the participants in this study relate, transnational networks of family and friends, or those established in Canada during weekends off, 
became indispensable resources of knowledge of the receiving society and were thus integral

motivators and links to finding their current jobs:

C: When I got my open permit, still I'm working as a live-out for the elderly people. Then, when I have my certificate now as a PSW, I work part-time in the agency first. They sent me here, they sent me there; you know, like a home care thing? And then, my sister helped me to get in part-time at [a nursing home] as a PSW, until now I'm working there full-time. At the same time before, I also work as a part-time at a rehab centre. This one my friend told me.

I: How did you find out about the agency?

C: Friends. That time. Cause once, the friends, one time they told you, they will tell you a lot of agencies anyways and I went to apply there every uh, you know...

I: Did you meet those friends here in Canada?

C: Oh yeah. Everybody now here in Canada. All my friends is a caregiver too that time. Yeah. Most of my friends non-immigrant [landed] too of course before. I still have no friends that are [landed] immigrant right away.

I: After you got your open work permit, what kind of work did you do?

D: I did live-out work but not like caregiving - I changed after I get my landed immigrant-like housekeeping. That's what I'm doing now because right now I have a lot of jobs [employers] so...I think since 2000 [year].

I: How did you find those jobs?

D: Through my friends.

I: Were all of these friends here in Canada before you?

D: Yes. We became friends when we're here [in Canada].

A: Before, at that time, [to get landed immigrant status] you're required to go to school. Yeah I went to school for first aid, but I don't want to work [in] a nursing home. I applied before [to] a post office so, I passed the exam and I select[ed] this one because of my

friend. We are the same [cohort] back home and she asked me to go and it's much better.

In the case of Participant F, she was encouraged by a friend to enroll in a medical lab assistant

program. Upon completion of the courses, the school at which she was enrolled was able to assign her a placement position at a local clinic:

Honestly, I don't know Toronto because I live in Pickering. From the time I landed here in Canada, my 4 years staying in Pickering [as a live-in caregiver], I just stay there. So, when I decided to get the PSW, I met my friend and she introduced me about the --school. Before, she's telling me to get the paralegal [course] because it's related to my course [in the Philippines], psychology. And then, all of a sudden, she's telling me about the medical lab assistant course so I was more interested to medical lab assistant than to paralegal. That's why I took that course and I said, before when I was in the Philippines, my ambition, like, my dream is to be a doctor. 
If social networks of family or friends did not directly secure a job for the participant women, they were nonetheless instrumental in providing knowledge of placement agencies or job openings. Also, as Participant F's case shows, social capital helped convince caregivers to pursue educational or skills upgrading courses that opened pathways to new areas of employment outside of domestic or care work. The accumulation and utilization of social capital in this case is a conscious choice towards achieving a position similar to her ambition to be a doctor.

However, the fact that all of the interviewees had completed a certificate in personal support work or other healthcare or service work-Participant E completed both a PSW and food handling certificate for example - places Participant F's outcome in the minority and supports the perceived tendency, examined in the literature above, that Filipina caregivers remain in domestic or care related occupations (Kelly 2007, 216; HRSDC 2013, Table $7 \&$ Table 12; McKay 2002, 26-27; Spitzer and Torres 2008, 20). The gendered, racialized and class based biases that surround these immigrant women persist and are arguably exacerbated by the social networks they possess. Social capital, as "[...] the product of investment strategies, individual or collective, consciously or unconsciously aimed at establishing or reproducing social relationships that are directly usable in the short or long term [...]" (Bourdieu 1986, 52), endorses the "double isolation" suggested by McKay $(2002,25)$. The information provided by fellow Filipina nationals influences the participants' conformity to racialized, gendered and classed notions of Filipina caregivers as "naturally domestic" (Macklin 1994, 21-22) through supporting their adherence to similarly domestic occupational sectors. Participant C's comment that even today, she still does not have any friends who have entered Canada individually as landed or skilled immigrants corroborates this point.

The case of Participant E provides the sole exception as she was unsuccessful in finding 
post-LCP employment via her family and friends:

Yeah I asked them [family and friends], but I don't know, they still don't find me a job. Before, I tried to look in the internet and I tried to attend a job fair but it's not good. I still rely on [an] agency because they're the one who's giving me a job. I used to rely on Career Foundation ${ }^{1}$ before when I don't have a job and I am under Employment Insurance benefits. So, they're the one who's helping me, giving me that website where I can look for the job search. I used to attend the training for resume writing. That's only like a seminar. But still no good! I did not find a job with that. It's still the agency is the one.

As her social capital resources were unable to adequately address the immediate needs of this participant, she returned to placement agencies that found her another job as a live-in caregiver for an elderly client with Alzheimer's. Albeit with a higher wage, 8 hour work days, weekends off and 2 home care personal support workers to relieve her (since the client requires 24-hour care), this participant's persistence in care work suggests other barriers to employment that other Filipina immigrants likewise face coming out of the FDM or LCP.

\subsection{Institutionalized and Embodied Cultural Capital: Structural and Social Barriers to}

\section{Settlement}

One of the most frequently mentioned barriers to the settlement and employment of the Filipina participants in this study is the inability to qualify for positions here in Canada for which they have trained or studied in the Philippines. Canada's lack of credential recognition, or the selective valorization of the institutionalized cultural capital of certain groups over others, and the deskilling perpetuated by years of in live-in caregiving work relegates these women to subordinate positions in the socio-cultural and socio-economic hierarchy. The foundation for this distinction was previously seen in the historically gendered and racialized ideologies and static

\footnotetext{
${ }^{1}$ A non-profit charity organization that provides job search and training resources in Toronto. See http://www.careerfoundation.com/
} 
perceptions assigned to domestic workers in Canada since the late nineteenth and early twentieth centuries. However, the social or behavioural markers of this group, their embodied cultural capital, are similarly influential. According to Bourdieu (1986, 49):

Because the social conditions of its transmission and acquisition are more disguised than those of economic capital, it is predisposed to function as symbolic capital, i.e., to be unrecognized as symbolic capital and recognized as legitimate competence, as authority exerting an effect of (mis)recognition [...].

Canadian society evaluates Filipina immigrants' skills and education through an essentialist lens that views their socio-cultural characteristics as legitimate indicators of their ability to contribute to the economy. While the previous section examined the outcomes of accumulating certain types of social capital, the accumulation of embodied cultural capital, read individual cultivation or "self-improvement" according to the institutionalized ideals of Canadian society (Bourdieu 1986, 48), can determine an immigrant's degree of upward socio-economic mobility and entails significant economic and temporal costs. For the study participants, these expenditures are often avoided. When asked why they did not take courses related to their area of study in the Philippines, some interview respondents explained:

F: When I was in caregiving job, I research regarding that psychology course and it's 3 years for that! So, I said, "What am I going to do? 3 years?" At the same time, I have to work because I don't have family here in Canada, only myself. So I have to support myself because you cannot ask somebody to support you, you know? Sometimes, even they're your friends but if money is involved, they're not your friend anymore, you know? So, it's hard, it's hard here in Canada.

C: So when I arrived here, I went to school as a part-time. You know ---? I went there and enrolled [in] the part-time subject of that course that I took in the Philippines that time but it's like, it's too much for me because it's only a part-time and then it's about money too. Yeah, so I just only take two courses. But I can't handle it. So then I dropped it, and then I took this PSW. Personal Healthcare Aid. It's more cheaper and it's at the time they give you, you know, the time that you can do it. Like the practice, that 300 hours, we're allowed to do it on the weekends. So I end up only with this. 
Similarly, Participant F relates the following about her friend who withdrew from the medical lab assistant course:

I don't know why she stop going back to school. Maybe because she had another plan. Like, for example, she's taking care of the 2 elderly right? And for her, that is a big money. Like, you know, they pay more. So, for her, if she go back to school, her time will be lost and her salary will be lost.

As the quotes above summarize, time and labour are commodities that transform embodied cultural capital into a form of "concealed economic capital" (Bourdieu 1986, 53-55) that these individuals cannot afford to lose. The costs of tuition and the time required to successfully complete a course takes away from the potential wages the women could be earning. Successful settlement in Canada is therefore an issue of prompt and gainful employment that comparatively shorter programs like personal support worker appear to fulfill. According to Participant F, for example, the medical lab assistant course she completed was 8 months long. Similarly, Participant D stated that she is considering taking a PSW course this September: "I think it's easy to find a job. That's what they said. I think it's 6 months [duration], but it's a hard job.” Participant G shares this perspective. Despite acknowledging that personal support work is a difficult job, the diverse motivations and priorities of the respondents are used to justify the acceptance of this type of work and reinforce the understanding that capital investment is a social, not just economic, strategy of agents.

During the transition process from temporary worker to permanent resident and citizen, the real or acquired notions of cultural comportment and behavioural symbols are attached to and transported with Filipina caregivers as they navigate Canadian society. While their institutional cultural capital goes unacknowledged, their perceived embodied cultural capital continues to influence their position within the larger society. That is, Filipinas in general are stereotypically viewed as nannies that embody ideal, domestic behaviour and humble values that legitimize their 
association as "career domestics" (McKay 2002, 25). As previously mentioned, Participant E, for instance, had encountered difficulty in finding employment through her social connections or a public job search organization after gaining permanent residency. As a result, she turned to the assistance of a placement agency that found her another position as a live-in caregiver:

I: When you started using the agency, how long did it take to find you a new job? E: Not too long. Like a month. Actually, I tried to look for like, a live-out or something like that...other job. But a lot of them, like food and handling, I can use that for my resume and then I apply for the restaurant, like that - for the kitchen. But they still need experience for at least 6 months, 7 months experience so...

I: What kind of experience?

E: Canadian experience, and so I'm not qualified for that job. So that's why it takes a long time before, when I'm looking for a job. 'Cause I tried another job but it's still no good for me. So I went back to taking care of an old lady, live-in. Because when I asked the agency, so when they look at my resume and then they look that I have more experience in taking care of an elderly, so they will give me an elderly. But a lot of elderly needs a live-in caregiver, not live-out. Yeah, they need someone who can stay with them until overnight, like that.

In spite of her diploma in food handling acquired in Canada, Participant E was deemed underqualified for work in the equivalent sector due to her lack of Canadian work experience. When she subsequently appealed to an employment agency, her previous experience in live-in caregiving work overshadowed her later educational accomplishments and she was given a similar job once again. The degree to which socially imposed gendered and racialized notions of cultural capital dictated this participant's motivations in returning to care work is not outwardly apparent from these statements, especially when she admits that the other jobs she tried were "not for her." Nevertheless, the structural barriers, or devaluated institutionalized capital that prevented her from getting a live-out position at a restaurant and the relative speed at which she was able to find her current caregiving position suggests these biases are enduring factors. In line with the existing literature on this ethnic group, caregiving experience continues to be seen as "invisible" work that cannot be counted as formal Canadian work experience. Only when 
conforming to the acquired standards of Filipinas' embodied cultural capital through remaining in the domestic service sector is this type of "experience" acknowledged. Therefore, racialized and classed understandings of the social position of domestic occupations remain static, albeit the economic demand for this labour is active and increasing.

The relationship shared between a Filipina caregiver and her employer while she is still a live-in domestic is another potential source of racialized stigma that can become the impetus for an immigrant acquiring alternative types of employment later. For example, Participant F displays a significant amount of individual agency in confronting her employer of 4 years who did not believe her capable of other kinds of work.

When I get my permanent resident [status], I decided to talk to my employer that I will go back to school. But you know, sometimes the people they don't really, like, seriously taking what you're saying right? Sometimes, if the employer they discriminate a nanny too because they think we are a Filipina, we don't know how to speak English well and we cannot go to school and listen to the teacher. Like it's hard for us [...] He's [her employer] telling me, "You have to sit in front so that you can really understand what the teacher's saying." But, I cannot disagree [with] what he's saying because "Ok, ok," I'm just telling [him] "Ok, ok." But in my mind, I said, "I'm not like that! How can I come here in Canada if I cannot understand people? If I cannot understand what you're saying?" And he's telling me that, "Oh, you cannot pass the exam." Like, hello? Don't judge me because you don't know me! And it's like, because you're new here in Canada right? Whatever they [employers] said, you just say, "Ok, ok." Like that. But inside, in your mind, you're like, your own thinking. So then, after that, I applied in --- and then, I passed my exam and then I told him, and he said, "Oh yeah, you're so smart!" I said, "Yes I am!" They think I cannot get through with this? "Wow," I said.

Although it was a friend who initially encouraged her to enroll in the medical lab technician program, the derogatory viewpoint of Participant F's employer, who expressed a racialized and classed assumption that Filipino immigrants are poorly versed in English and thereby incapable of other types of work, motivated her to successfully complete the course in order to disprove his claims. This motivation is central to Participant F's successful upward socio-economic mobility coming out of the LCP and her act of defiance challenges essentializing notions of Filipina 
immigrant's role in society or what Uma Narayan (2000) terms the "package picture of culture." However, this reaction is not typical of the rest of the study respondents.

\subsection{Employment Acquiescence and Settlement Satisfaction}

When faced with the economic, social, and structural/political barriers to upward socioeconomic mobility and settlement within Canadian society, participants' statements revealed an interpretation of successful settlement and integration as successful employment based on economic gain. The popularity of personal support work certifications among all of the study respondents speaks to the priorities of these women. For example, Participant $\mathrm{G}$ is employed as a PSW with a non-profit community support service agency that assigns care workers to elderly clients in their homes. When asked whether it was worth it coming to Canada she responded:

Yes. I am working like 7 years already for this company. The first time I said to you it's difficult because you're working like a maid. Everybody [Filipinas] doing that when they come here, it's difficult from the beginning. But if you finish that, then you study something here, then you're going to get a good job [...] Of course, it's a big, big difference! I am now a personal support worker, I am not a caregiver. I am not a private [worker]. I am working in a big agency in the government so I'm not working in a live-in.

This respondent clearly differentiates between the status and roles of caregivers, with whom she associates private, live-in duties, and personal support workers. According to this perspective, scholarly claims that Filipina immigrants coming out of the FDM or LCP are fundamentally consigned to low skilled domestic and caregiving work fail to consider the subjective circumstances of individual immigrant women or the different values they assign to cultural capital. Although she upholds essentialist views that all Filipinas coming to Canada work as caregivers, she also underscores her conscious choice to take PSW courses since "it's easy to get a job, you know." The structural barriers and social stigma requiring her to take these extra 
courses in the first place notwithstanding, she explained that her priority in settling in Canada is to provide for her two children who are also living with her.

Other participants share similar outlooks of resignation regarding their employment situations and degrees of satisfaction following FDM or LCP work. In response to the question “Are you satisfied with the job you are doing now?" Participant C replied: "Yeah. The one I have right now? Yeah because I have no choice and that's the only one I have the [PSW] certificate. Because this time around, it's hard to find a job now right? And if you don't have no certificate too, whatever kind of job [skills] you have, it's hard to get in [...]" By this, she goes on to explain the conditions at the nursing home at which she is currently employed:

Before, the people get in [hired] even though without certificate of PSWs or food handling or whatever [...] Then, there's a time now that some people doesn't have no certificate. So, they went to schooling to get a certificate for them to stay or else they're [the nursing home] going to kick them out because they said that's a government policy now, that you have to have one. And I'm hearing right now too that even though you are caregiver looking [after] elderly or disabled people, $[\ldots]$ that you have to have a certificate or [specialized] knowledge. So now, yeah, now, I'm happy now what I have.

The affirmative response of this participant is contradicted by her derogatory statement that she has no choice but to do PSW work. As previously examined, subjective valuations of institutional cultural capital are normalized within FDM and LCP policies that hinder the educational and professional advancement of these immigrant women, irrespective of their credentials in their home country. However, while Participant $\mathrm{C}$ was able to find her job at the nursing home through her sister, her reflections on contemporary labour markets reveal a contrasting decline in influence or profitability of social capital. More emphasis is being placed on institutional cultural capital obtained in Canada that is difficult and costly to access for Filipina immigrants. In addition, the first-hand experience these women have acquired from years of live-in caregiving work has been further undermined and invisibilized in the public 
sphere. As a result, Participant $\mathrm{C}$ expresses ambivalent satisfaction with her circumstances and, like Participant G, frequently mentions the need to support her two kids who are currently attending universities in Toronto.

On the other hand, although these participants' acceptance of their occupational positions in society aligns with the argument that cultural capital, especially in its institutionalized form, merely reproduces the status quo, the structural obstacles these women face and their priorities nevertheless portray a conscious strategy of gaining upward socio-economic mobility not for themselves, but for their children. Similar to the social capital strategies ("debt of gratitude") employed by Filipino families back in the home country (Betsayda 2008, 36; Bonifacio 2009, 138139), these participants are strategically investing their capital resources in the institutionalized advancement of their children in Canada. In this way, the participants overcome the intersectional social constructs that essentialize and disadvantage them as Filipino women and former live-in caregivers.

Other participants' acquiescence of their employment outcomes is presented as a matter of personal preference. The first narrative below describes the employment outcome of Participant E, who is still involved in live-in caregiving work today. She stated previously that she was unsuccessful in obtaining employment outside of caregiving after becoming a permanent resident —or that the jobs she tried were "no good" for her-so she returned to live-in work after seeking the aid of an agency. However, when asked whether she is satisfied with her current job she stated:

E. Actually, I have more experience now in taking care of an old lady so I think I want elderly better. Because I'm used to them, like, you know. I'm used to them because I work with them for many [more] years than the kids. The kids is only one year but the elderly is until now like, since 2006 until now. So I'm still taking care of elderly so... 
The following two responses are made by Participant B, a PSW working in a long-term elderly care facility in Toronto; and Participant A who is currently retired but had previously worked as a mailroom clerk:

B. I went to school and got a certificate for PSW, personal support worker. That's when I'm taking care of those old people [...] Well because I already have experience taking care of old people so I got this certificate from ---. I mean, yeah, I studied those typing [courses] before $[\ldots]$ but I didn't really like it.

A. I studied, like school—first aid, but I don't want to work in a nursing home. I don't want [like] the smell of medicine. That's why I work in the mailroom.

Since they are familiar with the duties involved in caring for elderly clients, Participants E and B expressed an overall preference or complacency with their present employment situations. Both also noted that they had previously tried alternative types of work or courses that did not appeal to them. Therefore, whether they are accustomed to caring for elderly clients or, like Participant A, they are bothered by medical environments, these respondents provided subjective rationalizations for their employment decisions that do not explicitly mention the economic, political and social barriers they faced. However, they make use of their experience and existing or acquired human capital as former live-in caregivers to arrive at their decisions.

Ultimately, while the intersectionality of social constructs like gender, race and class constructed the economic, political and social barriers the participants faced during their transition out of the FDM and the LCP, their individual utilization of the diverse forms of capital they possessed, as instrumental coping resources, aided them in interpreting the perceived success of their settlement outcomes. The testimony of Participant F provides a noteworthy example of the collective influence of social, economic and cultural capital in negotiating a place for immigrant Filipino women in Canadian society. 


\subsection{Individual Agency and Personal Motivation}

Participant F's transition narrative sharply contrasts those of her other comrade participants in that, in spite of the considerable incentives she received from social networks and former employers to take the medical lab assistant program, she ultimately credits her own personal motivation for her successful employment, and thereby settlement, in Canada. She is concurrently employed part-time at a clinic and a pharmaceutical research company in Toronto.

After having completed the medical lab assistant/technician course, the school at which she was enrolled found her a volunteer placement position at a walk-in clinic. Prior to and during this time, she was also doing piecemeal jobs as a housekeeper in order to earn an income for rent. Some months after her completion of the program, she was hired part-time by another clinic at which she is currently employed; it is also affiliated with the school, and this past December, she was hired on a part-time basis as a medical lab technician at the large pharmaceutical company.

Throughout all this, she continued doing her volunteer work at the first clinic and it is this

insistence on continuing to volunteer to which she ascribes her success:

Some of my friends, they finish medical lab assistant too right? Same as me. And after school, they try to apply as a medical assistant but their motivation is not really high [...] Before I got this job [at the pharmaceutical company], I'm doing as a part-time [at the clinic], you know. I just work Tuesday and alternate Saturday. So for Monday and the rest of the day that I don't go to school, if I don't go to work, I continue my volunteering. I volunteer without pay for 7 months. And I was telling to all my friends who finish the course medical lab assistant, you have to do it. You have to volunteer so when you met people and they know your work, they will refer you to other people right? And it shows up on your resume that you continue learning and you are interested on [in] this job. But, my friends saying that "Oh, how can you earn money?" Like this, like that. So you know, people is different. For me, I don't care if I just earn money. I don't know how I survive, I don't know how! But if you believe in yourself and you believe in God, no one's going to...you're not going to fail $[\ldots]$ and I'm telling that to all my friends. 
Participant F's perspective of success transcends valorizations of economic capital as she emphasizes that work experience and filling her resume are more important to her than income. Rather than merely embodying the stereotypical subservience and docile behaviour assigned to Filipino immigrant women, she highlights the significance of individual initiative in promoting one's knowledge and skills. This outlook exemplifies the interpretation of embodied cultural capital as an investment of self-improvement (Bourdieu 1986, 48) while continuing to uphold the social and economic value of institutionalized cultural capital. Further, she goes on to express a more pragmatic view of caregivers and caregiving work:

[...] you're doing the same thing. Same thing and same thing again and again. You know what I mean? Like, this day, you got to do this kind of job, the next day...Like for example, my work when I was a live-in caregiver like, Monday, I have to do the floor. Tuesday, I have to do the second floor. Thursday I have to do the bathroom. The next week, same thing. You know? It's not challenging you. It's so boring. That's why I thought maybe I feel bored or I feel like I have to do something else [...] But you know, sometimes people think it's better to work than go to school. They said, "Oh instead I'm going to school and I'm not earning, it's better for me to work. See I earn like this, I earn like that. I earn more money.” But, you don't think after you go to school, you're going to earn more than that?

This statement challenges the perception that remaining in caregiving occupations is more lucrative and argues instead that individuals should not become complacent in their current employment situations out of fear of economic loss. However, the revelation that individuals can earn more outside of caregiving work is subjective and inconsiderate of structural, economic or social barriers that necessitate immigrant women's retention of domestic occupations. Unlike other respondents as well, she does not have any immediate dependents with her in Canada who would potentially rely on her income. Participant F nonetheless exhibits individual agency in pursuit of a more stimulating occupation. Just as she chose to rely on social networks that encouraged her to take the medical lab assistant program, Participant F reproduces the social 
capital resource from which she benefitted through attempting to impart her experiences and motivation to her fellow caregivers.

For example, another key to her success is her knowledge and understanding of the different public funding services available to individuals interested in pursuing further education. The lack of understanding of OSAP is cited as one impediment to individuals' pursuit of educational upgrading: "Because sometimes people saying that 'Oh, OSAP, they're going to charge you more than what you have.' I said, 'No, it depends on your income tax. If you have less income tax, it's less pay for that.' They're scared about it. I said, 'No, don't be scared."' This view counters the economic barriers that some respondents referred to above; however, it also presents a contradiction. Participant F previously mentioned that she decided against pursuing a 3 year psychology program, the same subject as her degree in the Philippines, due to its duration and cost. Instead, she opted for the medical lab assistant program, an eight month program, which reinforces common temporal and structural vulnerabilities associated with livein caregivers' need to "start over" as permanent residents.

Nevertheless, Participant F's utilization of her social and cultural capital to complete her course and acquire a job as a medical lab assistant has allowed her to debunk some of the intersectional barriers imposed on immigrant Filipino women in Canadian society. Her immigration and settlement experiences dealt with similar social, economic and structural obstacles; however her management of these issues ultimately made her experiences and outcomes distinct from those of the other participants in this study. For Participant F, successful settlement and integration into the larger society involved not only gainful employment, but also the ability to reclaim the prestige and confidence that are often lost by Filipina immigrants entering Canada as live-in caregivers. For example, she recounts with pride how the school at 
which she completed her medical lab assistant course posted her picture and migration story in the department's classroom after her graduation. Ever since, other Filipina immigrants she is not acquainted with have approached her to congratulate her on her achievements after having seen this picture on the school bulletin board. Meeting these individuals provides Participant F with a source of inspiration, satisfaction and a sense of belonging in Canadian society:

That small thing makes you more motivated to do everything [...] You see? I'm here in Canada and I did all this kind of like, flattering [received all this flattery] here. Makes you more....in the society. Like, yes, you belong to this. You know? Because before, I don't really like talking to people when I work as a live-in caregiver. Now, I have more knowledge about the society. Before, I just stay home. My Saturday, Sunday just go to the mall and do shopping, that's it. It's not really productive [...] But now, see I can like - take for example, I pass my resume [to the pharmaceutical company] and even [though] it's part-time job, I'm happy for that. Because I said, "Oh wow, for all this applicants, they chose me to be part of their company." That's really compliment to yourself. So I said, "Wow, my life is really interesting!" I'm really thankful because of all this experience makes my personality more strong and more motivated to do and show the people that I can do anything.

Being acknowledged for her achievements and having her institutional cultural capital recognized by society elevates Participant F's socio-economic status and removes the stigma imposed on Filipina caregivers' employment potential. The ambitions of this respondent do not end here. She has recently completed the licensing exam for medical lab assistant/technician and subsequently plans to apply for a full-time position at a Toronto hospital. Participant $\mathrm{F}$ is adamant in spreading her success to her friends and fellow caregivers through advocating for their continued education and skills upgrading. Overall, her case presents a positive outcome of individual agency and personal motivation to combat against the inequalities faced by Filipina immigrants during their transition process out of the Foreign Domestic Movement or Live-in Caregiver Program. 


\section{Chapter 6}

\section{Conclusion and Recommendations}

Filipino women who enter Canada as live-in caregivers have received temporary status and limited rights that have perpetuated their subservience and exploitation as workers and as women since the late 1980s and early 1990s. In contrast to British women who were brought to the country as part of the state's nation-building agenda, women of colour or women from the "global South," such as Caribbean women in the 1950s, were increasingly admitted on a temporary basis to fill the demand for domestic workers and caregivers in Canadian households. Only after completing the terms of their employment contracts were these immigrants granted landed immigrant status and the associated labour and citizenship rights. This "global citizenship divide" (Stasiulis and Bakan 2005, 25) became entrenched in public policy through the Foreign Domestic Movement in 1982 and its successor, the Live-in Caregiver Program in 1992. These programs imposed single-employer, and live-in requirements on the women while they worked as caregivers for a minimum term of 24 months to be eligible for landed immigrant and permanent resident status.

Earlier studies, outlined in this paper, have remarked the inequalities perpetuated by these programs' policies as well as by social perceptions and norms imposed on the Filipina immigrants who make up the vast majority of entrants. Namely, the restrictions placed on their mobility and occupation contributes to their vulnerability within the unregulated homes of their employers. In addition, long wait times to process open work permits and PR applications, the deskilling that results from years of caregiving work, and the lack of foreign credential recognition ties them to similarly low skilled, invisibilized and poorly remunerated service 
occupations at the end of the programs. Federally and provincially funded immigrant settlement services are largely inadequate at meeting the employment and housing needs of post-FDM and post-LCP women. On the other hand, social stigmas and stereotypes relegate Filipina immigrants to the role of ideal, subservient domestic workers. Their commodified labour is contrastingly valorized yet derided in both the sending and receiving countries and the socio-economic demands placed on them juxtaposes with their own needs as individuals, thus attesting to the unwavering persistence of the gendered, racialized and classed ideals that underpin the political, economic and social criticisms made by scholars in the late 1980s to today.

The in-depth interviews of 7 Filipina immigrants in Toronto who entered under the FDM and LCP were analyzed for their alignment with or deviation from the above mentioned obstacles to settlement and integration into Canadian society. In particular, the ways in which success was interpreted by these participants were evaluated according to their valorization and investment of their different forms of capital. Coined by Pierre Bourdieu (1986), cultural capital—namely the "institutionalized" or educational qualifications and the "embodied" behavioural markers a person possesses-is representative of the social power structures or class hierarchy in place and into which individuals must conform. Social capital, the network of relationships individuals strategically develop, is instrumental to navigating this hierarchy. However, additional "systems of oppression" (Collins 1998, 63) or social constructs of race, gender and class also intersect these power relations and create the obstacles to settlement experienced by Filipina immigrants coming out of live-in caregiving work. Therefore, the appropriation of cultural and social capital as coping resources represents the priorities of the participants and their negotiation of belonging in Canadian society. 
Irrespective of their program of entry, the participants in this study mutually relied upon their social capital to find their current jobs, the majority of which are personal support work or other domestic related occupations such as housekeeper/cleaner. Similar social stigmas, economic deficiencies and obligations, and structural barriers hindered the employment, education and settlement pursuits of all respondents. Nevertheless, they all expressed sentiments of satisfaction, albeit resigned, regarding their employment and settlement outcomes. The accumulation and valorization of certain forms of capital over others, such as Participant F's motivation to complete her medical lab assistant course and realize the potential of her institutionalized cultural capital through obtaining equivalent employment, enabled some participants to establish a place for themselves in the larger society that transcended essentialist stereotypes of Filipina immigrants.

The findings of this study are significant to future research on this subject matter. While this project focused specifically on the viewpoints of Filipina former caregivers themselves, in highlighting their subjective empirical experiences and their diverse interpretations of the obstacles to settlement and integration for Filipina caregivers coming out of the Foreign Domestic Movement or the Live-in Caregiver Program, a similar approach can be applied to later studies on the perspectives of other influential players such as policy makers, middle-men recruitment agencies, or employers. 


\section{Appendix A: Interview Guide}

\section{Demographic information:}

- What is your name? (Will be replaced with a pseudonym or letter of the alphabet)

- What year were you born?

- What is your marital status?

- What was your marital status before leaving the Philippines?

- When did you arrive in Canada? (General year is fine) What was your status upon entering?

- What is your current immigration status?

- When did you gain an open work permit/permanent residency/citizenship? (Year or month and year)

- What is the highest level of education you completed in the Philippines?

- If gained a post-secondary or higher degree: What did you study?

- If gained lower than a post-secondary degree: Did you go through any training or courses in order to become a nanny/caregiver?

- What was your occupation in the Philippines?

- What are your current living arrangements? (I.e. live-in, rent, home owner, etc.)

Information on immigration experience, motivation, work experience and networks

- Was Canada your first destination? If no, in what other countries have you worked?

- Why did you decide to leave your home country and work as a nanny/caregiver?

- How did you find the job as a nanny/caregiver?

- Please describe your experience working as a nanny/caregiver.

-What were your day-to-day responsibilities?

○ Approximately how many hours per day did you work? 
- Were you given any time off?

- Have you kept in contact with your previous employer(s)?

\section{Settlement support, satisfaction, difficulties}

- What is your current occupation?

- How did you find this current job? Have you had any other jobs before this one?

- Where have you found the most support when looking for a job or a place to stay?

- If unemployed: What do you think is preventing you from finding employment or what are some challenges you are currently facing?

- Have you received any training or education in Canada?

- Have you ever accessed public settlement services for immigrants in Canada?

- If yes, which service(s)? Did you find them useful?

- If no, what were some possible reasons?

- Are you satisfied with the job you are doing now? Why?

- What do you enjoy most about your current job? What are some challenges/difficulties?

- Do you have children?

- If yes: How many?

- Do you have any family members back in the Philippines?

- Have you sponsored any family members to come to Canada?

Do you send money back home? 


\section{Appendix B: Informed Consent Form}

RYERSON

UNIVERSITY

\section{CONSENT TO PARTICIPATE IN RESEARCH}

Immigration and Settlement Experiences of Filipino Live-in Caregivers in Toronto

You are being invited to participate in a research study. Please read this Consent Form so that you understand what your participation will involve. Before you consent to participate, please ask any questions necessary to be sure you understand what your participation will involve.

My name is Mary Gene De Guzman, from the Graduate Program in Immigration and Settlement Studies at Ryerson University. This research study is being conducted as part of my Masters Major Research Paper.

If you have any questions or concerns about the research, please feel free to contact me at marygene.deguzman@ ryerson.ca

\section{PURPOSE OF THE STUDY}

I am interested in learning about the immigration experiences of Filipinos who came to Canada as live-in caregivers and their experiences after becoming Permanent Residents in terms of employment, job satisfaction, and social participation. I would especially like to explore the barriers these immigrants faced and the types of support they received during their settlement into Canadian society.

\section{DESCRIPTION OF THE STUDY AND YOUR PARTICIPATION}

If you volunteer to participate in this study, you will be asked to do the following things:

Participate in an interview lasting from 45 minutes to a maximum of 1 hour. You will be asked questions such as:

1) "Why did you decide to leave the Philippines?"

2) "What was your highest education in the Philippines/What did you study in the Philippines?"

3) "Where did you work after you became a Permanent Resident?"

4) "What do you think were the biggest obstacles you encountered as you settled in Canada?"

\section{POTENTIAL RISKS AND DISCOMFORTS}

Your participation in this study is $100 \%$ voluntary. The potential risks of this study are low; however, due to the personal nature of the interview questions and the memories or issues they invoke, you are free to refuse answering any question or withdraw from participating in this study altogether. If you decide to withdraw, all information collected about you will be 
immediately deleted or destroyed and you will not be contacted again. I will not disclose any information you give me to anyone.

\section{POTENTIAL BENEFITS TO PARTICIPANTS AND/OR TO SOCIETY}

I cannot guarantee, however, that you will receive any benefits from participating in this study. However, your participation will contribute to academic knowledge of the experiences of settlement, employment and social participation of Filipino immigrants in Canada.

\section{PAYMENT FOR PARTICIPATION}

You will not be paid to participate in this study.

\section{CONFIDENTIALITY}

With your consent, the information will be recorded by handwritten notes and audio device and will be kept under lock and key or password protection for one year. After this time, all information will then be deleted or destroyed. Only the researcher, Mary Gene De Guzman, will have access to this information.

All personal names and names of places will be replaced by pseudonym, or fake name, or a letter of the alphabet. You will also have the option of reviewing and/or editing a transcript of the recorded information. Confidentiality will be maintained to the fullest extent allowed by law.

\section{VOLUNTARY PARTICIPATION AND WITHDRAWAL}

Participation in this study is voluntary. You can choose whether to be in this study or not. If you volunteer to be in this study, you may withdraw at any time without consequences of any kind. If you choose to withdraw from this study you may also choose to withdraw your data from the study. You do not have to answer all questions. If a question makes you uncomfortable you can tell me you don't want to answer that. Your choice of whether or not to participate will not influence your future relations with the researcher or Ryerson University.

\section{QUESTIONS ABOUT THE STUDY}

If you have any questions about the research now, please ask. If you have questions later about the research, you may contact:

Mary Gene De Guzman (researcher): marygene.deguzman@ryerson.ca

Professor Rupa Banerjee (research supervisor): banerjee@ @yerson.ca

Phone: 416-979-5000 ext. 6733

This study has been reviewed by the Ryerson University Research Ethics Board. If you have questions regarding your rights as a research participant in this study, please contact:

Toni Fletcher, Research Ethics Coordinator

Research Ethics Board 
Office of the Vice President, Research and Innovation

Ryerson University

350 Victoria Street

Toronto, Ontario M5B 2K3

416-979-5042 or rebchair@ryerson.ca

\section{SIGNATURE OR ORAL CONSENT OF RESEARCH PARTICIPANT}

Your signature below indicates that you have read the information in this agreement and have had a chance to ask any questions you have about the study "Immigration and Settlement Experiences of Filipino Live-in Caregivers in Toronto" as described herein. Your questions have been answered to your satisfaction, and you agree to participate in this study. You have been given a copy of this form. If you have received this via email, you will be asked to verbally/orally give your consent before the start of the interview.

Name of Participant (please print)

Signature of Participant Date

Please sign below if you consent to the audio recording of your interview:

Signature of Participant

Date 


\section{Appendix C: Telephone Recruitment Script}

Hello, my name is Mary Gene De Guzman, I am a student at Ryerson University in the Immigration and Settlement Studies Graduate Program. I am currently conducting a research study on the immigration and settlement experiences of Filipinos in Toronto who came to Canada as live-in caregivers.

- I was wondering if I could speak to you about your experiences as a caregiver and your experiences after you gained an open work permit, permanent residency or citizenship.

- If you agree to speak to me, we could set up a time and place to meet up that is most convenient for you, or the interview could be conducted via telephone or Skype if you prefer. If you refuse to participate, your decision will in NO WAY impact your relationship to myself or Ryerson University (or organization name if applicable)

- The interview would take 45 min to maximum 1 hour and it will be audio recorded with your permission. I will also be taking hand-written notes. All recorded and shared information will only be accessible to me and it will be kept under lock and key and password protection until the end of the study. After that, it will be kept sealed and locked for one year and then it will all be destroyed. You will be free to revise any of the information if you wish. I can send you copies of the written interview or transcript via email or hard copy.

- I will not use your real name or the names of any other people or places you mention in any of our interviews in the study. The names will be replaced with another of your choice or a letter of the alphabet.

- If you are interested in participating in this study, I will provide you with a Consent Form which we will both sign and you can keep one for your records.

- Do you have any questions for me at this time regarding this study?

- If you have any questions or concerns, feel free to contact me at marygene.deguzman@ ryerson.ca or my cell: (XXX) XXX-XXXX.

Ending: Thank you very much for taking the time to speak to me. I look forward to our interview on (at)

If NO: Thank you very much for taking the time to speak to me. Have a nice day.

\section{If YES:}

- Face-to-face interview:

- Convenient Date:

○ Convenient Time:

- Convenient Place:

- I will bring a copy of the consent form to the interview that outlines everything I have just mentioned. I will require your signature if you agree to participate in the interview and I will also provide another copy for you to keep for your records. 
- Telephone interview:

○ Confirm phone \#:

○ Convenient Date:

○ Convenient Time:

- Skype interview:

○ Could you please let me know your skype name so I can add you?

My skype name is ---

- Skype name:

- Convenient Date:

- Convenient Time:

- Do you have an email address? Before the interview, I will send you a copy of the Consent form which outlines everything I have told you. I will require your oral consent prior to the start of the interview. I will remind you of this and ask for your consent before starting the interview.

○ Email:

\section{During Phone/Skype Interview:}

- Before we start, I will briefly go over the key points of the consent form you have received:

- The purpose of this study is to examine your settlement experiences and difficulties in Toronto as a former live-in caregiver.

- This interview will last from $45 \mathrm{~min}$ to 1 hour

- Your participation is $100 \%$ voluntary and if you feel like stopping your participation, please just let me know and I will destroy all notes/information I have received so far. The sensitive or personal nature of the questions may make some difficult to answer. If there are any questions that you are uncomfortable in answering, please let me know and you do not have to answer.

- I will be taking hand written notes as well as recording this interview with an audio recording device

- Only I will have access to the information of this interview but if you desire, I can send you a copy of the interview transcript for you to go over or revise

- Your name and the names of other people or places will not be included in the study. They will be replaced by pseudonyms or letters of the alphabet.

- There are no potential benefits for you in participating in this study besides contributing to academic knowledge

- The information in this interview will be stored by me under lock and key and password protection for up to 1 year after the end of this study and then will be immediately destroyed 
- Do you have any questions about the study? In case you have questions later on, my email is: marygene.deguzman@ryerson.ca

Please respond "Yes" or "No" to the following statements:

- I have read the information in the consent agreement and have had a chance to ask any questions I have about the study "Immigration and Settlement Experiences of Filipino Live-in Caregivers in Toronto." $\quad$ YES / NO

- My questions have been answered to my satisfaction. YES / NO

- I consent to participate in this study. YES / NO

- I consent to be audio recorded YES / NO

- I have been given a copy of the consent form YES / NO

- Again, I would like to remind you that everything you say in this interview will be recorded via audio tape and hand-writing with your consent. Only I will have access to this information.

- You are free to refuse responding to any question that bothers you and if you wish to stop participating at any time, please let me know and all information gathered will be immediately deleted/destroyed.

- All personal names will be replaced with another of your choice or a letter of the alphabet.

- Do you have any other questions before we begin? 


\section{References}

Arat-Koç, Sedef. 1997. "From 'Mothers of the Nation' to Migrant Workers." In Not One of the Family: Foreign Domestic Workers in Canada, edited by Abigail B. Bakan and Daiva Stasiulis, 53-79. Toronto: University of Toronto Press.

Arat-Koç, Sedef. 1999. "Neo-Liberalism, State Restructuring and Immigration: Changes in Canadian Policies in the 1990s." Journal of Canadian Studies 34:2, 31-56.

Arat-Koç, Sedef. 2012. “Invisibilized, Individualized, and Culturalized: Paradoxical Invisibility and Hyper-Visibility of Gender in Policy Making and Policy Discourse in Neoliberal Canada." Canadian Women Studies 29(3): 6-17.

Bakan, Abigail B. and Daiva Stasiulis.1997. "Foreign Domestic Worker Policy in Canada and the Social Boundaries of Modern Citizenship." In Not One of the Family: Foreign Domestic Workers in Canada, edited by Abigail B. Bakan and Daiva Stasiulis, 29-52. Toronto: University of Toronto Press.

Barber, Pauline Gardiner. 2004. "Contradictions of Class and Consumption When the Commodity is Labour.” Anthropologica 46: 203-218.

Betsayda, Mary Grace T. 2008. "'Bahala Na Ang Dios': The Church's Role in the Socialization of Filipinos in the Greater Toronto Area." Theses and Dissertations. Paper 78. http://digitalcommons.ryerson.ca/dissertations/78

Bonifacio, Glenda Lynna Anne Tibe. 2008. "I Care for You, Who Cares for Me? Transitional Services of Filipino Live-in Caregivers in Canada." Asian Women 24(1): 25-50.

Bonifacio, Glenda. 2009. "From Temporary Workers to Permanent Residents: Transitional Services for Filipino Live-in Caregivers in Southern Alberta." Our Diverse Cities 6: 136149. http://canada.metropolis.net/publications/odc09_pdfs/GlendaLynna_ODC09.pdf

Bourdieu, Pierre. 1986. “The Forms of Capital." In Handbook of Theory and Research for the Sociology of Education, edited by J. Richardson and translated by Richard Nice, 46-58. New York: Greenwood.

Bourgeault, Ivy Lynn; Rishma Parpia, and Jelena Atanackovic. 2010. “Canada's Live-In Caregiver Program: Is it an Answer to the Growing Demand for Elderly Care?" Journal of Population Ageing 3(1-2): 83-102.

Brazao, Dale. 2009. "Ruby Dhalla’s nanny trouble.” Toronto Star, May 05. http://www.thestar.com/news/investigations/2009/05/05/ruby_dhallas_nanny_trouble.htm $\underline{1}$

Brickner, Rachel K. and Christine Straehle. 2010. "The missing link: Gender, immigration policy and the Live-in Caregiver Program in Canada." Policy and Society 29(4): 309-320. 
Briones, Leah. 2009. Empowering Migrant Women: Why Agency and Rights are not Enough. England: Ashgate Publishing.

Cabanes, Jason Vincent A. and Kristel Anne F. Acedera. 2012. "Of mobile phones and motherfathers: Calls, text messages, and conjugal power relations in mother-away Filipino families." New Media and Society 14 (6): 916-930.

Carling, Jorgen, Marta Bivand Erdal and Rojan Ezzati. 2014. "Beyond the insider-outsider divide in migration research." Migration Studies 2(1): 1-19. http://migration.oxfordjournals.org/cgi/reprint/mnt022?ijkey=oaxS5eeyuQctTnj\&keytype $=$ ref

Castonguay, Marie-Hélène and Chakib Benzakour. 2010. "Insertion socioprofessionnelle des aides familiales résidantes." Canadian Issues: 42-44. http://ezproxy.lib.ryerson.ca/login?url=http://search.proquest.com/docview/610779579?a ccountid=13631.

CBC News. 2013. “GTA woman's monthly support helped family survive Haiyan.” November 21. http://www.cbc.ca/news/canada/toronto/gta-woman-s-monthly-support-helpedfamily-survive-haiyan-1.2435578

Chang, Grace. 2000. Disposable Domestics: Immigrant Women in the Global Economy. Cambridge, Mass: South End Press.

Chin, Christine B. N. 2005. "Neither at Work nor at Home: Asian Transnational Domestic Workers in Malaysia." In Asian Women as Transnational Domestic Workers, edited by Shirlena Huang, Brenda S. A. Yeoh and Noor Abdul Rahman, 262-287. Singapore: Marshall Cavendish Academic.

Chowdhury, Reshmi and Gloria Gutman. 2012. "Migrant Live-in Caregivers Providing Care to Canadian Older Adults: An Exploratory Study of Workers' Life and Job Satisfaction." Journal of Population Ageing 5 (4): 215-240.

Citizenship and Immigration Canada. 2010. "Minister Kenney announces improvements affecting temporary foreign workers, including live-in caregivers." News Release. August 18. http://news.gc.ca/web/article-en.do?m=/index\&nid=554169

Citizenship and Immigration Canada. 2012a. Canada Facts and Figures: Immigration Overview Permanent and Temporary Residents 2012. Minister of Public Works and Government Services Canada. Retrieved from www.cic.gc.ca/english/resources/statistics/menufact.asp

Citizenship and Immigration Canada. 2012b. "Become a permanent resident - Live-in caregivers." Last modified October 19. http://www.cic.gc.ca/english/work/caregiver/permanent_resident.asp 
Citizenship and Immigration Canada. 2013. "Live-in caregiver admissions to reach an all-time high in 2014." News Release. October 29. http://news.gc.ca/web/articleen.do?crtr.sj1D=\&crtr.mnthndVl=12\&mthd=advSrch\&crtr.dpt1D=6664\&nid=785269\&c rtr.lc1D=\&crtr.tp1D=1\&crtr.yrStrtVl=2002\&crtr.kw=\&crtr.dyStrtVl=1\&crtr.aud1D=\&cr tr.mnthStrtVl=1\&crtr.page $=2 \& c r t r . y r n d V l=2013 \& c r t r . d y n d V l=31$

Citizenship and Immigration Canada. 2014. "Preliminary tables - Permanent and temporary residents, 2013: Canada - Permanent residents by category, 2009-2013." Last modified June 17. http://www.cic.gc.ca/english/resources/statistics/facts2013-preliminary/01.asp

Cohen, Rina. 2000. "“Mom is a Stranger': The Negative Impact of Immigration Policies on the Family Life of Filipina Domestic Workers." Canadian Ethnic Studies/Études ethniques au Canada 32(3): 76-89.

Collins, Patricia Hill. 1998. "It's All in the Family: Intersections of Gender, Race and Nation." Hypatia 13(3): 62-82.

Cristaldi, Favia and Joe T. Darden. 2011. "The Impact of Immigration Policies on Transnational Filipino Immigrant Women: A Comparison of Their Social and Spatial Incorporation in Rome and Toronto." Journal of Urban History 37(5): 694-709.

De Leon, Conely. 2009. "Post-Reunification Reconciliation among PINAY Domestic Workers and Adult Daughters in Canada." Canadian Woman Studies 27(2): 68-72.

Employment and Social Development Canada. 2014. "Hiring Live-in Caregivers and Nannies." Last modified July 4. http://www.esdc.gc.ca/eng/jobs/foreign_workers/caregiver/index.shtml\#EducationTraining

England, K. and B. Stiell. 1997. “'They think you're as stupid as your English is': constructing foreign domestic workers in Toronto." Environment and Planning A 29: 195-215.

Foreign Domestics: The Right to Stay. 2011. Directed by Anthony Domingo Y. Valdez. Channel SCN 266. Citytv: Television.

Gabriela Transitions Experiences Survey. 2014. 'From 'Migrant' to 'Citizen': Learning from the Experiences of Former Caregivers Transitioning out of the Live-in Caregiver Program.” Preliminary Analysis. July 22. http://www.gatesurvey.com/wpcontent/uploads/2014/07/GATES-Preliminary-Analysis-201407221.pdf

Grandea, Nona. 1996. Uneven Gains: Filipina Domestic Workers in Canada. Edited by Philippines-Canada Human Resource Development Program, Ont. North-South Institute. Ottawa: Philippines-Canada Human Resource Development Program (PCHRD). 
Guevarra, Anna Romina. 2003. "Manufacturing the 'Ideal' Workforce: The transnational labor brokering of nurses and domestic workers from the Philippines." PhD diss., Order No. 3111350, University of California, San Francisco. http://ezproxy.lib.ryerson.ca/login?url=http://search.proquest.com/docview/305341282?a ccountid=13631.

Human Resources and Skills Development Canada. 2013. Evaluation of the Labour Market Opinion Streams of the Temporary Foreign Worker Program: Final Report September 2012. Ottawa, Canada: Human Resources and Skills Development Canada http://www.hrsdc.gc.ca/eng/publications/evaluations/skills_and_employment/2013/tempo rary foreign.pdf

Kapiga, Isabelle. 2009. "Agents of Change, Colours of Resistance: The Socio-Economic Integration of Filipina Live-in Caregivers in Montreal." Masters diss., Order No. MR67277, Concordia University (Canada). http://ezproxy.lib.ryerson.ca/login?url=http://search.proquest.com/docview/807456698?a ccountid=13631.

Kaplan, C. \& I. Grewal. (1994). Transnational Feminist Cultural Studies: Beyond the Marxism/Poststructuralism/Feminism Divides. Positions, 2(2), 430-445.

Kelley, Ninette and Michael Trebilcock. 2010. A Making of the Mosaic: A History of Canadian Immigration Policy. Toronto: University of Toronto Press.

Kelly, Philip and Tom Lusis. 2006. "Migration and the transnational habitus: evidence from Canada and the Philippines." Environment and Planning A 38: 831-847.

Kelly, Philip F. 2007. "Transnationalism and Political Participation among Filipinos in Canada." In Organizing the Transnational: Labour, Politics, and Social Change. Edited by Luin Goldring and Sailaja Krishnamurti, 215-231. Vancouver: UBC Press.

Keung, Nicholas. 2014. "Filipino Canadians fear end of immigrant dreams for nannies." The Toronto Star, July 22. http://www.thestar.com/news/immigration/2014/07/22/filipino_canadians_fear_end_of_i mmigrant_dreams_for_nannies.html

Lan, Pei-Chia. 2003. "Maid or Madam? Filipina Migrant Workers and the Continuity of Domestic Labor." Gender and Society 17(2): 187-208. DOI: 10.1177/0891243202250730

Lee, Eunjung and Marjorie Johnstone. 2013. "Global Inequities: A Gender-Based Analysis of the Live-in Caregiver Program and the Kirogi Phenomenon in Canada." Affilia 28(4): 401414.

"Live-in Caregiver Program: The grey zone in immigration policy." 2009. The Globe and Mail (1936-Current), May 16. 
http://ezproxy.lib.ryerson.ca/login?url=http://search.proquest.com/docview/1371274661? accountid=13631.

Macklin, Audrey. 1994. "On the Inside Looking In: Foreign Domestic Workers in Canada.” In Maid in the Market: Women's Paid Domestic Labour, edited by Wenona Giles and Sedef Arat-Koç, 13-39. Halifax: Fernwood Publishing.

Martin Spiegelman Research Associates. 2000. Building Community: A Framework for Services for the Filipino Community in the Lower Mainland Region of British Columbia.

Vancouver, BC: City of Vancouver, Canadian Heritage, Mosaics, 65. http://www.mosaicbc.com/sites/all/files/publicationspublic/Filipino_Community_Profile.pdf

McClelland, Susan. 2005. "Nanny Abuse.” The Walrus, March

McKay, Deirdre. 2002. "Filipina Identities: Geographies of Social Integration/Exclusion in the Canadian Metropolis." Working Paper Series 02-18, Vancouver Centre of Excellence: Research on Immigration and Integration in the Metropolis. http://mbc.metropolis.net/assets/uploads/files/wp/2002/WP02-18.pdf

McKay, Deirdre. 2003. "Filipinas in Canada - De-skilling as a Push toward Marriage." In Wife or Worker: Asian Women and Migration, edited by Nicola Piper and Mina Roces, 23-52. Oxford: Rowman \& Littlefield Publishers Inc.

McKay, Deirdre. 2005. "Success Stories? Filipina Migrant Domestic Workers in Canada." In Asian Women as Transnational Domestic Workers, edited by Shirlena Huang, Brenda S. A. Yeoh and Noor Abdul Rahman, 305-340. Singapore: Marshall Cavendish Academic.

Narayan, Uma. 2000. “Undoing the 'Package Picture' of Cultures." Signs: Journal of Women in Culture and Society 25(4): 1083-1086.

Philippine Women Centre-Ontario. 2014. "Canada's live-in caregiver program continues to be a nightmare for Filipinos." National Statement, August 8. http://www.magkaisacentre.org/2014/08/08/lcp-a-nightmare-for-filipinos/

Pratt, G. and PWC. 2003. "From Migrant to Immigrant: Domestic Workers Settle in Vancouver, Canada." Research on Immigration and Integration in the Metropolis, Working Paper Series No. 03-18 Vancouver, RIIM. http://mbc.metropolis.net/assets/uploads/files/wp/2003/WP03-18.pdf

Pratt, Geraldine. 2006. "Separation and Reunification among Filipino Families in Vancouver." Canadian Issues / Thèmes Canadiens 3: 46-49.

Semyonov, Moshe and Anastasia Gorodzeisky. 2005. "Labor Migration, Remittances and Household Income: A Comparison between Filipino and Filipina Overseas Workers." International Migration Review 39(1): 45-68. 
Solomon, M. Scott. 2009. "State-led Migration, Democratic Legitimacy, and Deterritorialization: The Philippines' labour export model." European Journal of East Asian Studies 8(2): 275-300.

Spitzer, Denise, and Sara Torres. 2008. "Gender-Based Barriers to Settlement and Integration for Live-in Caregivers: A Review of the Literature.” CERIS Working Paper No. 71. Toronto, Ontario.

Stasiulis, Daiva Kristina and Abigail B. Bakan. 2005. Negotiating Citizenship: Migrant Women in Canada and the Global System. Toronto: University of Toronto Press.

The Nanny Business. 2010. DVD. Directed by Shelley Saywell, Deborah Parks, Deborah Palloway et al. Toronto: Bishari Film Productions, 2010.

Wells, Kathleen. 2011. Narrative Inquiry. Oxford Scholarship Online. DOI: 10.1093/acprof:oso/9780195385793.001.0001 